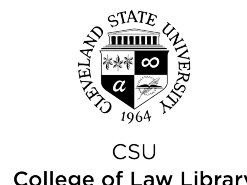

Cleveland State University

College of Law Library

\title{
EngagedScholarship@CSU
}

\section{Taking Stare Decisis Seriously: A Cautionary Tale for a Progressive Supreme Court}

James G. Wilson

j.wilson@csuohio.edu

Follow this and additional works at: https://engagedscholarship.csuohio.edu/fac_articles

Part of the Constitutional Law Commons

How does access to this work benefit you? Let us know!

\section{Original Citation}

James G. Wilson, Taking Stare Decisis Seriously: A Cautionary Tale for a Progressive Supreme Court, 10 Journal Jurisprudence 327 (2011)

This Article is brought to you for free and open access by the Faculty Scholarship at EngagedScholarship@CSU. It has been accepted for inclusion in Law Faculty Articles and Essays by an authorized administrator of EngagedScholarship@CSU. For more information, please contact research.services@law.csuohio.edu. 


\section{HEINONLINE}

Citation: 10 J. Juris 3272011

Content downloaded/printed from

HeinOnline (http://heinonline.org)

Wed Sep 12 10:40:30 2012

-- Your use of this HeinOnline PDF indicates your acceptance of HeinOnline's Terms and Conditions of the license agreement available at http://heinonline.org/HOL/License

-- The search text of this PDF is generated from uncorrected OCR text. 
THE JOURNAL JURISPRUDENCE

\title{
TAKING STARE DECISIS SERIOUSLY
}

\author{
James G. Wilson*
}

\section{Abstract}

This article assumes that President Obama's election begins a gradual progressive transformation of the Supreme Court. To help determine the appropriate scope of judicial review, should such a change arise, the article separates stare decisis analysis into descriptive and normative factors. To build the model, it uses closely contested cases, won by conservatives. Even if one does not agree with this article's particular normative assessments of any particular issue, the descriptive model is an important contribution to the enduring debate about the role of precedent in constitutional adjudication. The model also demonstrates the virtual impossibility of having any systematic theory of stare decisis.

This article recommends that any future liberal Court should not be very "judicially active." It should be reluctant to overturn many prior conservative victories or to create numerous novel constitutional rights. Liberals may balk at this proposal. On the other hand, conservatives will dislike the article's ideological assumption that our society needs to move in a much more progressive direction. I fear excessive judicial activism could undermine any political effort to create a widespread Congressional coalition to resolve such pressing issues as environmental degradation, resource depletion, wealth inequality, and economic decline. For example, a liberal Court should not eliminate the individual's right to bear arms under the Second Amendment set forth in Heller, because it would alienate white, rural working class voters. This article is not standard fare.

\section{Introduction}

This article hypothesizes that President Obama's 2008 election signified a political/constitutional shift, similar to President Nixon's triumph in 1968. After Nixon's victory, American Presidents selected Supreme Court nominees who were more conservative than the Warren Court majority. ${ }^{1}$ At this point, it is impossible to predict Justice Sotomayor's and Justice Kagan's constitutional

\footnotetext{
* Professor, Cleveland State University.

${ }^{1}$ Republican successes in the 2010 midterms demonstrate that Obama's election may not have been a major turning point.
}

(2011) J. JURIS 327 
jurisprudence, but they may not be very aggressive. ${ }^{2}$ But should they be? Any emerging liberal majority would have the power to revisit closely contested constitutional decisions that earlier liberals lost-the five-to-four and six-tothree conservative victories that have been the focus of most liberal political and academic ire. To help answer that question, this constitutional hypothetical reconsiders many narrowly decided cases, won by conservatives, to create a descriptive model of stare decisis which lawyers across the political spectrum should find useful.

The article's normative perspective is more disquieting: many liberals will disagree with the degree of deference it gives to prior adjudications, while many conservatives will oppose the primary reason for that passivity: the Supreme Court needs to withdraw more from the political arena, particularly the Culture Wars, to enable average Americans to find common ground to elect leaders who will address such pressing issues as economic decline, wealth inequality, resource depletion, and environmental degradation. ${ }^{3}$ For example, liberals should not revisit the limited right of individuals to bear arms established in Heller v. District of Columbia and McDonald v. Chicago. ${ }^{5}$ Overruling those opinions would alienate many white, rural citizens needed for significant political change. Thus, this approach is more cautious than most of the proposals set forth in The Constitution in 2020. ${ }^{6}$ In that book, liberal scholars primarily discussed how current constitutional doctrine should be improved. None of the chapters dwelled on stare decisis, particularly as applied to conservative opinions.

No single factor is determinative under stare decisis. The wide range of justifications favoring stare decisis (and the countervailing reasons to ignore precedent) often conflict and are frequently incommensurable. Stare decisis requires a malleable adjudicatory methodology that should drive anyone seeking a unified theory of constitutional law to despair. Any Justice who is thinking of overruling a prior case has to compare the earlier case's reasoning, outcome, and impact with that Justice's own complex constitutional ideology, which should contain a significant degree of deference to precedent. This article structures this multifaceted process by first considering "descriptive factors," variables that are relatively easy to measure. It next looks at normative factors most lawyers support. Finally, it considers the more divisive norms that are at

2 See Jeffrey Tobin, Bench Press: Are Obama's Judges Really Liberals?, THE NEW YoRKমR, Sept. 21, 2009 , at 32 .

3 This argument also applies to any future liberal creation of numerous "new rights" and to moving far beyond the text to create unenumerated rights and powers. See, e.g., MARK V. TUSHNET, TAKING THE CONSTITUTION AWAY FROM THE COURT (2000).

4554 U.S. 570 (2008).

5561 U.S. (2010).

6 See Jack M. Balkin \& Reva B. Siegel, The Constitution in 2020 (2009).

(2011) J. JURIS 328 
the heart of any controversial decision. Stare decisis means, at a minimum, that new Supreme Court Justices should integrate their constitutional jurisprudence into the existing framework, even though they would have decided many prior cases differently.

By focusing on selected closely-contested cases, itself a major stare decisis factor, this essay is only a first step in understanding the Court's steady drift to the right. A thorough analysis would consider all previous cases. However, the daunting task of making an overall assessment of conservative jurisprudence, which has recently become far more assertive, requires someone as gifted, inspired, and sympathetic as the late John Hart Ely, who eloquently and gracefully reconfigured existing constitutional law to strengthen most Warren Court jurisprudence while criticizing such controversial decisions as Roe $v$. Wade. ${ }^{7}$ Nevertheless, this article's less ambitious inquiry, which sifts through the battleground of contentious cases with an often saddened and skeptical eye, may assist anyone attempting to duplicate Ely's dazzling achievement.

The choice between retaining and reversing any decision resides deep within the soul of each adjudicator. The article's final section briefly reconsiders Citizens United v. Federal Election Commission. ${ }^{8}$ Five Justices overruled Austin v. Michigan Chamber of Commerce, which held that legislatures could regulate corporate political speech. Believing that Citizens United threatens any healthy conception of republican government, this article recommends that Citizens

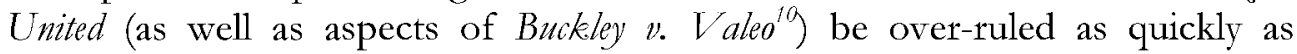
possible.

\section{Descriptive Factors}

In Citizens United, the lead opinion and the dissenting opinion reduced the number of stare decisis factors to four: workability, antiquity of the precedent, the reliance interests at stake, and whether the decision was well-reasoned. ${ }^{11}$ Numerous considerations reside under those factors. Rather than duplicate the Court's approach, this section discusses several additional, traditional stare decisis factors that are relatively easy to ascertain: the number of Justices initially favoring a challenged opinion, the number of concurring opinions, the form of the doctrine, and subsequent litigation.

\footnotetext{
${ }^{7}$ John Hart Ely, Democracy \& Distrust: A Theory of Judicial Review (1980).

8558 U.S. 1 (2010).

9494 U.S. $652(1990)$.

10424 U.S. 1 (1976).

11 Id.(Stevens, J., dissenting).
}

(2011) J. JURTS 329 


\section{A. Longevity of Precedent}

Nothing is easier than determining the date when the Court decided a prior opinion. But that seemingly straightforward issue requires the Court to consider the other three Citizens United factors. If the challenged opinion has been around for many decades, it has proven to be somewhat "workable." Any decline in workability has probably been caused by subsequent judicial (and even popular) hostility towards the doctrine, rather than the doctrine itself. Long-enduring opinions also imbed themselves into the nation's cultural and legal system, generating "reliance." Such opinions have a patina of authority. On the other hand, more recently decided opinions reflect current mores and understandings - making them more salient and possibly more controversial. Plessy $v$. Ferguson, for instance, had survived the test of time, was easy to enforce, helped create and perpetuate the Southern racial system, and provided a pseudo-egalitarian doctrine that kept the Supreme Court from confronting the South for many decades. Today, almost everyone thinks Plessy was poorly reasoned because of its odious results, not just its cruelly abstract doctrine. Furthermore, the date of the challenged opinion can obscure a crucial issue, the longevity of the challenged practice. In Citizens United, the Court struck down a relatively recent decision, but the legislative branches had prohibited direct corporation contributions for over a century. Thus, the conservatives ignored a "constitutional tradition" that is also part of the constitutional calculus.

\section{B. Initial Distribution of Votes and Concurrences}

1. Closely-Contested Cases

Why focus on closely contested cases, the five-to-four and six-to-three opinions won by Justices conventionally considered "conservative?" First, Justices have emphasized the closeness of the original vote. ${ }^{12}$ Because so many Supreme Court opinions have so many political ramifications, a divided opinion usually reflects a divided electorate, while a unanimous opinion often intimates widespread agreement. There is a perpetual tension between the elite and the masses in this society, as in every other. American leaders, including Supreme Court Justices, risk a severe backlash if they deviate too far from overall public

\footnotetext{
${ }^{12}$ See, e.g., Payne v. Tennessee, 501 U.S. 808 (1991), overruling Booth v. Maryland, 482 U.S. 496 (1987) and South Carolina v. Gathers, 490 U.S. 805 (1989) (justifying the inapplicability of state decisis, in part, because the two prior cases "were decided by the narrowest of margins, over spirited dissents challenging the basic underpinnings of those decisions"). Conversely, unanimous decisions deserve greater reverence. See Hubbard v. United States, 514 U.S. 695, 723 (1995) (Rehnquist, C.J., dissenting), (denouncing the majority's "disregard [for] the respect due a unanimous decision").
}

(2011) J. JURIS 330 
opinion. De Tocqueville acutely described the limits of legal authority in the United States:

The majority [of the people in the United States], therefore, exercise a prodigious actual authority, and a moral influence which is scarcely less preponderant; no obstacles exist which can impede, or so much as retard its progress, or which can induce it heed the complaints of those whom it crushes upon its path. ${ }^{13}$

This essay seeks to avoid facile reductionism: many decisions cannot be explained in terms of partisan politics or immediate ideological preferences. Indeed, one of the stare decisis's virtues is that its norm of judicial consistency can trump those impulses. The process of common law adjudication, like all forms of practical reason, cannot be reduced to a few variables. Some cases are "hard" because there is a basic lack of agreement among the Justices about what should be done. Others are "hard" because Justices are caught in a constitutional crossfire: various factors pull in opposing directions. Indeed, the doctrine of stare decisis remains perpetually murky and erratic in application because it asks a Justice to trump other, more contemporary norms leading the Justice to believe an opinion was initially misguided. ${ }^{14}$ Such tensions, which create malleable uncertainty, are desirable. Stare decisis pulls a Justice away from the immediate political world and reinforces his or her institutional commitment to the legal system. To the degree that a tradition is strong, validated by longevity and by an initial decision that cuts across the existing, albeit forever shifting conservative/liberal divide, the new Justice should be more willing to abide.

\section{Concurring Opinions}

Along with close votes, another indicator of doctrinal vulnerability is a plethora of concurring opinions. While most five-to-four opinions raise the straightforward question of whether or not one agrees with the decision, the multiple-opinion case is harder to decipher. ${ }^{15}$ That lack of guidance weakens

\footnotetext{
13 1) TOCQUEVIJ].H, supra note _ at 301.

${ }^{14}$ See Michael Stokes Paulsen, Does the Supreme Court's Current Doctrine of Stare Decisis Require Adherence to the Supreme Court's Current Doctrine of Stare Decisis?, 86 N.C. L. R匹V. 1165,1171 (2008) ("What defines the doctrine of stare decisis as a judicial practice - which gives the doctrine any punch at all - is adherence to what a court, by hypothesis, otherwise would regard as an erroneous exposition of law.").

15 The Court has adopted a singular approach for determining the "holding" of a plurality decision. "When a fragmented Court decides a case and no single rationale explaining the result enjoys the assent of five Justices, 'the holding of the Court may be viewed as that position taken by those Members who concurred in the judgments on the narrowest grounds . ..." Marks $v$.

(2011) J. JURIS 331
} 
these cases, making them less "workable." Conversely, such complex determinations are easier to retain, because future Justices can seize upon language in a concurrence to alter the primary opinion.

Except during the Civil Rights era and the Civil War, federalism has been of more interest to the intelligentsia than the average citizen. For conservative lawyers, it has been a rallying point: they named their most influential and famous organization The Federalist Society. Supreme Court Justices Rehnquist, Kennedy, O'Connor, Scalia, and Thomas have often protected States from the federal government and individual litigants. ${ }^{16}$ Putting that norm into practice has not always been easy. United States $v$. Lopez attempted to shift much power from the federal government to the States by limiting Congressional power under the Commerce Clause. ${ }^{17}$ In that five-to-four decision, conservatives invalidated a federal law criminalizing bringing firearms into public schools. ${ }^{18}$

However, the conservatives failed to speak with a unified voice. In his majority opinion, Chief Justice Rehnquist found that the federal government overreached for several reasons: (1) Congress failed to demonstrate that guns in schools had a substantial effect on interstate commerce; ${ }^{19}$ (2) Congress failed to require the prosecution to provide adequate proof that it had jurisdiction; ${ }^{20}$ (3) the defendant had not engaged in any economic transaction; ${ }^{21}$ (4) States had primary responsibility for running school systems; ${ }^{22}$ and (5) Congress cannot easily expand the scope of federal criminal law. ${ }^{2.3}$ Justice Thomas' ambitious concurrence questioned much Congressional legislation since the New Deal: "I am aware of no cases prior to the New Deal that characterized the power flowing from the Commerce Clause as sweepingly as does our substantial effects test. *** If anything, the 'wrong turn' was the Court's dramatic departure in the 1930's from a century and a half of precedent." 24 In their concurrence, Justices O'Connor and Kennedy repudiated Thomas's vision: "Congress can regulate in the commercial sphere on the assumption that we

United States, 430 U.S. 188, 193 (quoting Gregg ข. Georgia, 428 U.S. 153, 169 n.15 (1976) (opinion of Stewart, Powell \& Stevens, JJ.))

${ }^{16}$ See Ernest A. Young, The Rehnquist Court's Two Federalisms, 83 TH.x. L. RH.V. 1 (2004).

17 United States v. Lopez, 514 U.S. 549 (1995); see also Chris Marks, Comment, U.S. Term Limits, Inc. v. Thornton and United States v. Lopez: The Supreme Count Resuscitates the Tenth Amendment, 68 U. COLO. L. REV. 541, 553-564 (1997).

${ }^{18}$ Loper, 514 U.S. at 551.

${ }^{19}$ Id. at 561.

20) Id. at 561-62.

${ }^{21} I d$. at 561.

${ }^{22}$ Id. at $564-66$.

${ }^{23} I d$. at $562-67$.

${ }^{24}$ Id. at 596,599 .

(2011) J. JURIS 332 
have a single market and a unified purpose to build a stable national economy." 25 These concurrences represent a major ideological split among judicial conservatives. Indeed, the fate of the recently passed Health Care bill will probably come down to Justice Kennedy's application of his concurrence's general principle to the requirement that individuals must purchase health care from private insurance companies.

While some conservatives foresaw a constitutional revolution, ${ }^{26}$ many liberal critics believed that the Court would apply Rehnquist's criteria in a haphazard, result-oriented way of little importance. ${ }^{27}$ The main beneficiaries would be lawyers and legal theorists, who would argue endlessly about Rehnquist's factors, which had replaced the prior bright line rule completely deferring to Congressional use of the commerce clause power in social and economic situations. ${ }^{28}$ The Kennedy/O'Connor approach prevailed, which came as little surprise, because O'Connor and Kennedy have been the crucial swing votes in most closely contested cases. There has been no wholesale assault on regulatory capitalism at the constitutional level. The conservatives have struck down a few laws, most notably Congress's attempt to provide more protection to women by criminalizing gender-motivated violence in United States $\nu$. Morrison. ${ }^{29}$ But majorities have erratically applied the malleable factors in Loper in ways that can best be explained by the ideological preferences of the Justices (it is harder to determine the viewpoints of Justices who uphold challenged laws, because one cannot know if they personally supported the law or just found it a valid exercise of legislative power). According to fluctuating majorities on the Court, Congress could protect the privacy of state drivers' licenses from intrusive questioning $^{30}$ and prohibit the use of freely distributed medical marijuana even though there was no commercial transaction. ${ }^{31}$ Overall, there has been no cataclysm, merely erratic confusion. ${ }^{32}$

${ }^{25}$ Id. at 574 .

${ }^{26}$ See, e.g., Marcia Coyle, Washington Gets Amendment Fever, NAT'L L.J., June 5, 1995, at A1 (quoting Professor Bernstein of New York Law School stating "We're seeing the most remarkable shift in public thinking about government and where governmental responsibilities should be placed since FDR.").

27 See, e.g., Barry C. Toone \& Bradley J. Wiskirchen, Great Expectations: The Illusion of Federalism After United States v. Lopez, 22 J. LEGis. 241, 264 (1996).

28 See, e.g., Wickard v. Filburn, 317 U.S. 111 (1942).

29529 U.S. 598 (2000).

${ }^{30}$ Reno v. Condon, 528 U.S. 141 (2000).

${ }^{31}$ Gonzales v. Raich, 545 U.S. 1 (2005).

32 Many commentators have discussed the ambiguous status of federalism in the Supreme Court after Gonqales. See e.g., Lino A. Graglia, Essay, Lopez, Morrison, and Raich: Federalism in the Rehnquist Court, 31 HaRv. J.L. \& Pub. POL'Y 761 (2008); Casey J. Carhart, Note, Will the Ever(2011) J. JURIS 333 
What should be done with this potpourri of cases and doctrines? A liberal majority would never join Justice Thomas's crusade against the New Deal. However, they should not overrule Loper and Morrison. First, the decisions have not done much damage. The States can and do punish those who carry guns into schools and commit sexually motivated assaults on women. ${ }^{33}$ The existence or nonexistence of the law in Morrison would have little, if any, deterrent effect on would-be rapists. ${ }^{34}$ Second, it is easy to apply this commerce clause doctrine less rigorously. Congress can establish relatively trivial jurisdictional requirements, such as requiring that the Justice Department prove that any gun brought into a school contains parts manufactured outside the state..$^{35}$ If the liberals wish to reconsider Morrison without overruling Lopez, they can easily manipulate the degree of deference to Congressional "findings," stating that Congress has provided sufficient evidence. There is no objective way to infer when a legislature has proven the "need" to do something after considering a wide range of studies, listening to testimony, and gathering anecdotes. ${ }^{36}$ Behind every legal inference lurks a complex jurisprudence. Furthermore, there is hardly any judicial adjective more malleable than "substantial" and any judicial noun pliable than the casual notion of "effects." 37

A future progressive Court also might want to consider keeping Lopez alive, if not totally ambulatory. One mixed blessing of Loper is that it makes it more difficult for Congress to plunge into the cultural wars that have divided and distracted this country for decades. If Congress cannot pass a law protecting women from sexual assault when the States have been enforcing such laws for centuries, Congress may not be able to punish adultery, overconsumption of junk food, teenage drinking, homosexuality, and flag burning. Admittedly, the Court has protected some of these activities under other textual provisions, ${ }^{38}$ but there is no harm in having two constitutional bulwarks instead of one. Of course, it is hard to draw any principled, easily applicable constitutional line in

Swinging Pendulum of Commerce Clause Interpretations Ever Stop? A Casenote on Gonzales v. Raich, 27 WHITTIER L. REV. 833 (2006)

${ }^{3}$ Loper, 514 U.S. at 581.

${ }^{34}$ See (Owen D. Jones, Sex, Culture, \& the Biology of Rape: Toward Explanation \& Prevention, 87 CAL. L. REV. 827, 924 (1999).

35 See Lopez, 514 U.S. at 561-62 (implicitly providing for a jurisdictional hook which would render a commerce clause quandary moot); Morrison, 529 U.S. at 611-12.

37 See Gonzales, 545 U.S. at 67 (Thomas, J., dissenting) ("T'] he 'substantial effects' test is a 'rootless and malleable standard' at odds with the constitutional design.") (quoting Morrison, 529 U.S. at 627 (Thomas, J., concurring)).

38 See, e.g., Lanvence v. Texas, 539 U.S. 558 (2003) (striking down Texas anti-sodomy statute); Texas v. Jobnson, 491 U.S. 397 (1989) (providing First Amendment protection to flag burning as expressive conduct);

(2011) J. JURIS 334 
terms of the commerce power. Most of us want the federal government to prosecute kidnappers and terrorists, even when they are uninterested in money. Nor can liberals easily protect medical use of marijuana: the federal government should be able to outlaw any drug it believes is dangerous, whether purchased or not.

Because legal reasoning resembles a simultaneous equation containing numerous variables, this article's choice of a contested case, as it just did with Lopez, to exemplify particular stare decisis variables can be misleading. All the factors influence or should influence any reconsideration (of course, this article's list of factors is contestable in terms of inclusion, omission, and exclusion). In other words, there are other, more important reasons why Lopez should or should not be retained than the fact that the winning side spoke with three different voices.

\section{A. The Form of the Doctrine}

For quite some time, there has been a debate about the comparative value of "bright line" rules versus "balancing tests." Justice Scalia asserted in a law review article that the "rule of law" should consist of the "law of rules," i.e., bright lines." On the Court, he has frequently castigated his colleagues for employing pliable balancing tests, for acting like "Mr. Fix-it." Justice Scalia is overreacting: just as it is useful to regulate traffic with posted speed limits, which are rigid rules, it is also desirable to supplement those laws with the more indeterminate standard of "reckless driving," even though that standard gives police discretion that they may abuse. This section considers how the Court's chosen form of doctrine interacts with stare decisis without concluding that either form is innately preferable. Rules and standards have different, foreseeable effects, costs, and benefits. ${ }^{42}$ To the degree that a doctrine is a formal rule requiring little or no discretion in application, it is difficult to distinguish or dilute. ${ }^{43}$ A party easily wins whenever it can prove the facts that trigger the rule. Thus, bright line rules provide "workability" because of ease of applicability. Yet balancing tests provide a different type of "workability" due to their flexible responsiveness to different fact patterns.

\footnotetext{
${ }^{39}$ See, e.g., James G. Wilson, Surveying the Forms of Doctrine on the Bright Line - Balancing Test Continuum, 27 ARIZ. ST. L.J. 773 (1995) [hereinafter "Forms of Doctrine"]. 40) Antonin Scalia, The Rule of Law as the Law of Rules, 56 U. CHI. L. REV. 1175 (1989).

${ }^{41}$ See Hamdi v. Rumsfeld, 542 U.S. 507, 576 (2004) (Scalia \& Stevens, J., dissenting).

${ }^{42}$ See Kathleen M. Sullivan, The Justices of Rules \& Standards, 106 HARV. L. R『V. 22 (1992).

${ }^{43} I d$. at 58.
}

(2011) J. JURIS 335 
The Supreme Court has created many constitutional bright lines. Loretto $\nu$. Teleprompter Manhattan CATV Corporation ${ }^{44}$ held that a city ordinance had "taken" a landlord's property by requiring installation of cable facilities. Although the "permanent physical invasion" of the building was trivial, the government must compensate the owner. ${ }^{45}$ This bright line rule protects two of the most important rights in real property's bundle of rights: exclusion ${ }^{46}$ and personal use. ${ }^{47}$ Future plaintiffs simply prove "permanent physical invasion," the occupation of their land for significant time. ${ }^{48}$ There will be few evidentiary or inferential problems (unlike determining if taking a gun into school substantially impairs interstate commerce). It will be hard for future courts to persuasively distinguish Loretto in similar situations, such as requiring property owners to permit cellular phone towers without payment. Admittedly, there will be squabbling at the margin over the meaning of the adjective "permanent,"49 but the rule is quite predictable. Indeed, the Supreme Court has only applied Loretto in one other case. ${ }^{50}$ Loretto should remain on the books. Holmes observed that there is no better reason for a law than its resonating with deep human instincts. ${ }^{51}$ People do not like other people putting things on their property without permission. ${ }^{52}$ Many years ago, many Americans destroyed telephone poles put on their property when that new technology spread across the land..$^{53}$

The Court created another bright line in takings jurisprudence in Lucas $\%$. South Carolina Coastal Councip $p^{4}$ by holding that a State could not pass laws stripping a

\footnotetext{
44458 U.S. 419 (1982).

${ }^{45}$ Id. at 434-35.

46 See Kaiser Aetna v. United States, 444 U.S. 164, 179-80 (1979); see also Int'l News Serv. `y. Associated Press, 248 U.S. 215, 250 (Brandeis, J., dissenting).

${ }^{47}$ Loretlo, 458 U.S. at 436.

${ }^{48}$ Id. at $437-38$.

49 See Loretto, 458 U.S. at 436 n.12. There has been some debate the meaning of "permanent." Compare Hendler III, 952 F.2d at 1376 ("'P]ermanent' does not mean forever, or anything like it."), and Boise Cascade Corp. \%. United States, 296 F.3d 1339, 1356 (Fed. Cir. 2002) (asserting Hendler "merely meant to focus attention on the character of the government intrusion necessary to find a permanent occupation, rather than solely focusing on temporal duration.")

50) See Brown v. Legal Found. of Wash., 538 U.S. 216, 235 (2003).

51 Oliver Wendell Holmes, The Path of the Law, 10 HARV. L. REV. 457, 477 (1897)

52 Property owner do not want cellular towers sited anywhere near their property, See Steven J. Eagle, Wireless Telecommunications, Infrastructure Security, and the NIMBY Problem, 54 CATH. U. L. REV. 445 (2005).

53 Eula Bliss, The War on Telephone Poles, HARPER's MAG., Feb. 2009 at 19. See also War on Telephone Poles, N.Y. Times, Feb. 6, 1889 at 1.

54505 U.S. 1003 (1992)
}

(2011) J. JURIS 336 
piece of property of all value. When people buy land, it is a reasonably foreseeable risk that the government may pass future laws diminishing the value of their land (zoning is most obvious), ${ }^{55}$ but nobody would like to buy land knowing that the government can legislate the land's value out of existence by precluding any development. According to the Court, that extreme loss is constitutionally unacceptable. ${ }^{56}$ Investors would pay less for real property (particularly wetlands) if they knew the government could wipe them out. Extreme cases cry for judicial intervention. Imagine the Army Corps of Engineers building a dam that floods private property ${ }^{57}$ or a law precluding owners from utilizing their land because the owners disturb an endangered species: the owners would only retain title and tax liability. These bright line rules create a bulwark against governmental bad faith, of confiscation via regulation. Any future Court would be under great pressure to explain how and why it chose to alter them. These cases show how bright line rules resist change differently than factor tests, which require Courts to consider different variables having little or no commensurability, or balancing tests that usually include a conclusory adjective. ${ }^{58}$ Thus, Justices can best embed their fears and aspirations in such rigid rules. Because a bright line is harder to dilute or distinguish, an unsympathetic majority must accept the rule and its applications, replace it with a different doctrine, or overrule it. Unless a Court wants to disrupt massive amounts of constitutional law, it will leave many of these workable rules alone.

\section{Balancing Tests}

It is hard to take Justice Scalia's dichotomy between rules and standards too seriously, because he has frequently joined conservative majorities that replaced bright lines with balancing tests, as in Loper, and has sometimes created his own pliable doctrine. In Nolan v. California Coastal Commission, ${ }^{59}$ he held that the Commission acted unconstitutionally by requiring beachfront property owners to provide public access to a beach before rebuilding their home. He claimed that the "nexus" between the end (increased public access) and the means (regulating home construction) was so tenuous that California had engaged in "a plan of out-and-out extortion." "There is no simple way to evaluate the "fit" ends and means. It is even harder to determine when the government is invoking a legitimate power as a "pretext" for an unconstitutional act, which in this context consisted of "extortion." Courts determine the quality of the fit

\footnotetext{
55 See Penn. Coal Co. v. Mahon, 260 U.S. 393, 413 (1922).

56 Luas, 505 U.S. at 1019.

57 This is exactly what occurred to property owners in Jacobs $\nu$. United States, 290 U.S. 13 (1933).

58 See Forms of Doctrine, supra note _, at $806,819$.

59483 U.S. 825 (1987).

${ }^{60}$ Id. at 837 (quoting J.E.D. Assocs., Inc: v. Atkinson, 121 N.H. 581, 584 (1981).
}

(2011) J. JURIS 337 
between claimed ends and means by evaluating evidence, ${ }^{61}$ relying upon "common sense," ${ }^{, 62}$ assessing alternatives solutions, ${ }^{6,3}$ and predicting effects. The Supreme Court infers bad intentions when it concludes governments have gone "too far." In addition, the doctrinal field of "unconstitutional conditions" is remarkably resistant to grand theory. ${ }^{65}$ There is a legal consensus on and off the Court that the government has more constitutional discretion when determining how to spend its own money than when regulating others. ${ }^{66}$ But here, the government is imposing a condition on a private party without providing any of its own money. Still, some of these conditions are acceptable; States can require health, safety, aesthetic, and environmental building permits. The problem is one of degree, not of kind, as reflected in Scalia's slippery "nexus" test.

Justice Scalia joined Chief Justice Rehnquist's subsequent opinion, Dolan \%. City of Tigard, which added a balancing requirement to Scalia's inferential "nexus" test. ${ }^{67}$ The City would not allow to a businesswoman to expand her store unless she dedicated part of her undeveloped land to flood control and a public bike path. ${ }^{68}$ The Chief Justice found that the conditions "fit" because dedicating land to flood control limited flooding, unlike the situation in Nolan, where there was no obvious relationship between rebuilding a home and public access to a beach. ${ }^{69}$ But he asserted that there was a disproportionate relationship between the impact of the future development on the environment and the impact of the condition on the owner." "Proportionality" is another classic balancing test. $^{71}$ One tipping factor, as in Nolan, was the City's interference with the plaintiffs right to exclude others, "one of the most essential sticks in the

\footnotetext{
${ }_{61}$ Dolan, 512 U.S. at 392-96.

62 See Johnson v. California, 321 F.3d 791, 801 (2003), rev'd, 543 U.S. 499 (2005).

${ }^{6.3}$ City of Cincinnati v. Discovery Network, Inc., 507 U.S. 410, 418 n.13 (1993).

${ }^{64}$ Mahon, 260 U.S. at 415 ("While property may be regulated to a certain extent, if regulation goes too far it will be recognized at a taking."); see also Vieth v. Jubelirer, 541 U.S. 267, 335 (2004) (Stevens, J., dissenting) ("[W] hen race is elevated to paramount status - when it is the be-all and end-all of the redistricting process - the legislature has gone too far.").

65 See, e.g., Larry Alexander, Impossible, 72 DEN. U. L. R匹V. 1007 (1995) (characterizing the development of a unifying theory for unconstitutional conditions as "impossible"); Kathleen M. Sullivan, Unconstitutional Conditions, 102 HARV. L. REV. 1416 (1989) ("TT]he doctrine of unconstitutional conditions is riven with inconsistencies.").

66 See Rust v. Sullivan, 500 U.S. 173, 192-95 (2000); National Endowment for Art v. Finley, 524 U.S. 569, 571 (1998).

67512 U.S. at $388-91$.

${ }^{68} \mathrm{Id}$. at $379-80$.

69) Id. at $377-78$.

${ }^{70}$ Id. at 394-96.

71 See K.G. Jan Pillai, Incongruent Disproportionality, 29 HASTiNG CONST. L.Q. 645 (2002).

(2011) J. JURIS 338
} 
bundle of right," by demanding a public path. ${ }^{72}$ But no bright line was created. ${ }^{73}$ Future Courts must compare the size and expense of the development with the costs and benefits of legal requirements.

Nolan and Dolan present a future liberal Court with several choices: (1) Should they jettison the doctrines either by overruling them or replacing them? (2) Should they reverse the particular outcomes but limit the doctrines' future impact? Or (3) Should they extend the reasoning to similar situations? The two cases protect Loretto's core rights. It would be very troubling if a City could "condition" a landlord's application for a building permit upon the builder's allowing the government to invade the property with cable devices. At some point, the government has gone "too far," unless one believes that the government has unlimited power to condition permits. Although Dolan and Nolan remain debatable - as the five-to-four opinions indicate-they provide some guidance and constraints on governmental abuse. At the least, the Court should be skeptical of efforts to force landowners to admit more people on their property (whether along a beach or on a bike path). Also, the cases have not spawned a massive amount of litigation strangling the government's ability to regulate development. ${ }^{74}$ How should these cases be applied in the future? It is hard to say: it depends upon the particular condition.

These examples demonstrate how rules are both stronger and weaker than balancing tests in terms of stare decisis. Rigid rules' strengths of clarity, ease of application, predictability, and durability give future Justices less maneuvering room, which eventually may provoke a judicial backlash. Almost ironically, rules need the doctrine of stare decisis more than balancing tests. Balancing tests bend but need not break, ${ }^{75}$ while bright lines force future Justices into "allor-nothing" positions.

When Courts invalidate a rule, they need a doctrinal replacement. After all, they have not just tossed out a rule, but also its existing and likely applications. However, some of the situations covered by the existing rule might warrant continuing protection. An inability to formulate better doctrine is another reason to maintain the status quo. For instance, the Court usually creates a bright line for a powerful reason-it perceives the particular factual issue exemplifies a "core right," "core interest," or "core power" that could and

\footnotetext{
72 Dolan, 512 U.S. at 393.

73. See Damon Christian Watson, Dolan and the "Rough Proportionality" Standard: Taking Its Toll on Loretto's Bright Line: Dolan v. City of Tigard, 114 S. Ct. 2309 (1994), 18 HAlRv. J.L. \& PuB, POL'Y 591 (1995).

${ }^{74}$ Cf. Carlos A. Ball \& Lawie Reynolds, Exactions e` Burden Distribution in Takings Law, 47 WM. \& MARY L. REV. 1513, 1559-60 nn.219-221 (2006).

75 Sullivan, supra note _, at 66-67.
}

(2011) J. JURIS 339 
should be easily and aggressively protected. ${ }^{76}$ Here, the Court is attempting to protect the core property right of exclusion and prevent the classic governmental abuse of confiscation. Bright lines prevent further incursion. To the degree that many people instinctively believe the Court initially handled the core example properly, it is harder for future Justices to reject the doctrine and future applications. Thus, any liberals who want to get rid these four cases should create alternative doctrine, which is likely to be more imprecise but still prevents the injustices identified in those cases.

\section{B. Formal Equality}

When invalidating a state law levying a special operations tax on a national bank in Mc Culloch v. Maryland, ${ }^{77}$ Chief Justice Marshall utilized numerous, enduring constitutional arguments. The Court should deferentially assess the "necessity" (the "fit") between Congress's chosen means, a national bank, and its constitutionally authorized ends, which included financing the military. ${ }^{78}$ Courts cannot easily determine the degree of "necessity." Marshall next all but declared Maryland's tax to be pretextual, designed to destroy the national bank instead of to raise revenue. ${ }^{80}$ Marshall condemned the tax's focus on bank operations. ${ }^{81}$ However, he conceded that the State retained power to tax federal entities in the same fashion that it taxed its citizenry. ${ }^{82}$ In other words, States could pass a generally applicable tax on wages or land that applied to the national bank. ${ }^{83}$ Universality, by its very nature, reduces the likelihood of legislative abuse; voters would not support representatives who pass punitive taxes that apply to them as well an unpopular national bank. ${ }^{84}$ Furthermore, the targeted bank was tempting; states could reap a profit. They would collect revenues from citizens living outside Maryland, who had paid federal taxes supporting national banks. ${ }^{85}$ There would be taxation without representation. ${ }^{86}$

\footnotetext{
76 See, e.g., R.A.V. v. St. Paul, 505 U.S. 377, 422 (1992) (Stevens, J., concurring) ("Our First Amendment decisions have created a rough hierarchy in the constitutional protection of speech. Core political speech occupies the highest, most protected position ...").

7717 U.S. (4 Wheat.) 316 (1819).

${ }^{78} \mathrm{Id}$. at $408-410,421-423$.

79) Id. at 421.

8) Id. at 431 .

${ }^{81}$ Id. at $436-37$.

82 Id. at 436 .

${ }^{8.3}$ Ultimately, the Court later concluded that federal employee salaries are not immune from taxation by the states. See Graves v. O'Keefe, 306 U.S. 466 (1939).

84 MoCulloch, 17 U.S. (3 Wheat.) at 428.

${ }^{85}$ Id. at 435 .

${ }^{86}$ Id. at 431.
}

(2011) J. JURIS 340 
Marshall created workable doctrine of formal equality that simultaneously authorized and limited governmental power. Formal equality is constitutionally attractive for many reasons. Governments lose the presumption of constitutionality when focusing on constitutionally-protected parties or interests. Maryland had failed to create "common law," law common to all. Also, formal equality often generates bright line rules, providing the benefits and costs that come with such rules, particularly ease of enforcement. Such rules make the Court appear more judicial: the higher the level of generality, the greater the appearance of impartiality. Finally, formally equal rules are very powerful. Some interest groups cannot overtly impose their unconstitutional preferences. For example, Brown 1 . Board of Education's prohibition of racist public school systems prevented the racist interest group from using this despicable tool of oppression.

New York v. United States ${ }^{87}$ followed Marshall's approach. Justice O'Connor invalidated a federal law targeting States by requiring them to take title to undesirably expensive nuclear waste generated by private parties whenever States refused to participate in the federal disposal program. ${ }^{88}$ At the same time, she allowed Congress to pass formally neutral laws that equally burdened States and private parties: ${ }^{89}$ Congress could prohibit States from discriminating on the basis of age, ${ }^{90}$ disability, ${ }^{91}$ or race ${ }^{92}$ and could impose broad environmental laws. ${ }^{93}$ Just as Marshall's opinion prevented Maryland from destroying the bank, so New York made it much harder for Congress to evade administrative and financial responsibilities by imposing unique obligations on the States and/or requiring State officials (aside from State judges) to enforce laws they did not make. If New York had gone the other way, corporations would have obtained an attractive way to obtain state subsidies without the state voters' participation. ${ }^{94}$ The tactics were not just coercive, but also a usurpation of State legislative power. ${ }^{95}$ Imagine a federal law requiring States to assume toxic bank assets if they didn't implement a particular regulatory regime. Or even worse, a

\footnotetext{
87505 U.S. 144 (1992).

${ }^{88} \mathrm{Id}$. at 149 .

${ }^{89} I d$. at 160 . Justice O'Connor cites several cases in which the Court had previously upheld generally applicable laws, including Garia v. San Antonio Metro. Transit Autbority, 469 U.S. 528 (1985).

90) Age Discrimination in Employment Act of 1967, 29 U.S.C. $\iint 621$ - 634 (2006).

${ }^{91}$ Americans with Disability Act of 1990, 42 U.S.C. $\iint 12101$ et seq. (2006).

92 See Title VII of Civil Rights Act of 1964, 42 U.S.C. SS 2000e et seq. (2006).

${ }^{33}$ See, e.g., Clean Water Act of 1972, 33 U.S.C. $\$ \$ 1251$ et seq. (2006); Clean Air Act of 1963, 42 U.S.C. \$\$ 7401 et seq. (2006).

94 Wilson, supra note _ at 1693-94.

95 Nem York, 505 U.S. at 176 (asserting that the federal action would "commandeer state governments into the service of federal regulatory purpose").
}

(2011) J. JURIS 341 
federal law transferring private toxic private debts to the States. After New York, the corporations and the States will form natural alliances against general federal legislation. The "political safeguards of federalism" work much better when the States have private power as an ally instead of a predator.

Formal equality does not solve all constitutional problems: it can exacerbate underlying social problems that legislatures should be able to address. Moral philosophers from Aristotle to Thomas Nagel have observed that most political disputes can be framed in terms of competing conceptions of equality for which there is no self-evident ranking. The Court usually can choose between competing conceptions of formal equality, just as it can choose between competing conceptions of "rights." Brown's prohibition of segregation was as "formally equal" as Plessy v. Ferguson's "separate but equal" doctrine", the rule that Brom explicitly overruled. Plessy arguably did not "discriminate" on the basis of race because it required (in theory but not in practice) ${ }^{97}$ that States provide equal educational resources to all children. Some political analysts have criticized formal equality's tendencies. In the Second Discourse, Rousseau did not describe the formation of the social contract as an agreement among equals. ${ }^{98}$ Rather, the rich and the poor were in such a state of perpetual conflict that the rich gave up some of their power by implementing a system of formal equality, a system that would calm the masses but would not destroy wealth and power. ${ }^{99}$ The result, to paraphrase Anatole France, is that the rich and the poor have an equal right to live in their car after foreclosure. ${ }^{100}$ John C. Calhoun warned the North that its formally equal tariffs discriminated against the South by driving up the cost of imports and strengthening Northern manufacturing. ${ }^{101} \mathrm{He}$ observed that the Constitution was not well designed to combat this unconstitutional sectional economic warfare and that violence was likely. ${ }^{102}$ Lochner $\%$ New York, ${ }^{103}$ another major case that the Court eventually overruled, ${ }^{104}$

96163 U.S. 537 (1896).

97 See Anthony LeWis, Portratt of a Decade: The SECond amERICan Revolution 20 (1964) (describing the disparity in 1915 where South Carolina spend $\$ 23.76$ per white pupil and only $\$ 2.91$ on the average African-American child).

98 Jean-Jacques Rousseau, On the Origin of Inequality (Trans. G.D.H. Cole, Cosimo 2006) (1754).

${ }^{99}$ Id. at 78-79.

100) See ANatole France, The Red Lily 95 (Trans. Winifred Stephens, John Lane 1910) ("The law, in its majestic equality, forbids the rich as well as the poor to sleep under bridges, to beg in the streets, and to steal bread.").

101 John C. Calhoun, South Carolina Exposition and Protest (1828) (decrying the effect of the Tariff system in which "its burdens are exclusively on [the South] and its benefits on [the North]).

$102 \mathrm{Id}$.

103198 U.S. 45 (1905).

104 Or at least implicitly overruled in Williamson v. Lee Optical of Oklahoma, 348 U.S. 483 (1955).

(2011) J. JURIS 342 
constitutionalized the common law's formally equal rules of contract that assume equality of bargaining power. ${ }^{105}$ More recently, Derrick Bell and many other liberals have challenged the claim that the Constitution must be "colorblind," an aspiration found in Justice Harlan's dissent in Plessy, because that standard threatens affirmative action. ${ }^{1116} \mathrm{By}$ ignoring a long history of legal, cultural, and economic inequality, colorblindness perpetuates those injustices' effects. ${ }^{107}$

The affirmative action controversy is a classic example of interest group politics being played out at the constitutional level. In an ideal world, the Constitution should be completely "color blind," hostile to all laws using race as a category. Nevertheless, affirmative action may be a necessary evil, justified by past injustices and future necessities (such as having a fully integrated officer corps to effectively lead our troops), but it will always remain under a constitutional cloud due to its incompatibility with the more universal norm. So what should be done about the Supreme Court's current affirmative action doctrine, which has virtually eliminated the tool except for higher education in Bakke? ${ }^{118}$ Future progressives will be tempted to permit States and the federal government to use affirmative action in hiring, firing, and contracting at all levels, but that judicial counterattack will alienate many citizens. Thus, liberal Justices should seriously consider retaining Parents Involved in Community Schools v. Seattle School District, which struck down plans to desegregate public schools by considering race, because that case did not involve higher education. ${ }^{109}$ Conversely, conservatives should be wary of overruling Bakke, which could encourage Hispanic voters to support the Democratic Party. The divisive issue should be left in its awkward doctrinal limbo. The current doctrine provides access for many of the most gifted members of all racial groups, diffuses racial tensions, and facilitates diversity within the military, the academy, business, and politics. ${ }^{110}$

\footnotetext{
105 See Cass R. Sunstein, Lochner's Legay', 87 CoLum. L. REv. 873, 882 (1987).

106 Derrick A. Bell, Race, Racism, and American Law 115-135 (5th Ed. 2004)

107 Id. at $126-35$.

108 Regents of the University of California v. Bakke, 438 U.S. 265 (1978).

109127 S. Ct. 2738 (2007).

110 These institutions passionately supported University of Michigan's affirmative action policy in Grutter v. Bollinger, 539 U.S. 306 (2003). See Brief of the Society of American Law Teachers as Amicus Curiae in Support of Respondents (Feb. 19, 2003), 2003 WL 399060; Brief of the Association of American Medical Colleges, et al., as Amici Curiae in Support of Respondents (Feb. 14, 2003), 2003 WL 398338; Brief for Graduate Management Admission Council and the Executive Leadership Council as Amici Curiae in Support of Respondents (Feb. 14, 2003), 2003 WL 399157.
}

(2011) J. JURIS 343 


\section{Subsequent litigation}

Hindsight makes the stare decisis inquiry somewhat easier than the process of making the original decision. Future courts can evaluate how the legal system has applied existing law and the doctrines' social consequences. There are at least four ways to use subsequent litigation to measure doctrinal strength: (1) Does the rule generate numerous cases? (2) Are the later disputes over application of the rule to new facts?; (3) Is the Supreme Court itself still disputing the wording of the rule? (4) Is the scope of the rule growing, shrinking, or relatively stable?

\section{Abandoned Doctrine}

The absence of additional cases may indicate that a doctrine has been "abandoned." 111 Or, it can indicate success. In Casey, the plurality would not give "zombie doctrines" stare decisis protection. ${ }^{112}$ It is not easy to diagnose abandonment. For instance, in the past few decades, the Supreme Court has only held twice that States have unconstitutionally impaired contracts between private parties. ${ }^{113}$ In Allied Structural Steel $\%$ Spannaus, ${ }^{114}$ the Court concluded that the State could not impose "severe" new pension obligations upon a Corporation for a group of workers who had previously worked for the company for ten years. Writing for a five Justice majority in a five-to-three case, Justice Stewart assessed the law for its "reasonableness" and "necessity." "115 This case could have revived laissez-faire constitutionalism. ${ }^{116}$ However, two subsequent decisions $^{117}$ indicated that the Court was not going to apply Spannaus vigorously; as a result, the case is currently a footnote in most constitutional law textbooks, a bit of a constitutional sport, significantly limited to its facts and factors. Although not directly on point because it involved the federal government, Pension Benefit Guaranty Corp. v. R.A. Gray \& Co. ${ }^{118}$ emphasized retroactivity as the most important constitutional variable.

111 "The doctrine of stare decisis is at its nadir when the rule in question has been effectively abandoned by the erosion of time, rendering its rationale obsolete." Casey, 505 U.S. at 857.

112 Casey, 505 U.S. at 857.

11.3 See Allied Structural Steel v. Spannaus, 438 U.S. 234 (1978); United States Trust Co. v. New Jersey, 431 U.S. 1 (1977)

114438 U.S. 234 (1978).

115 Id. at $242,247$.

${ }^{116}$ Richard Epstein, Toward a Revitalization of the Contracts Clause, 51 U. Chi. L. Rev. 703 (1984).

117 Exxon Corp. v. Eagerton, 462 U.S. 176 (1983) (restricting Spannaus' application to statutes whose "sole effect was to alter contractual duties"); Keystone Bituminous Coal Ass'n v. DeBeni, 480 U.S. 470 (1987).

118467 U.S. 717 (1984).

(2011) J. JURIS 344 
Despite their narrow scope and their potential for future disruption, these two cases should be retained. There is a general presumption against retroactivity in the Constitution, ${ }^{119}$ a presumption that serves many of the same purposes as statutes of limitations. ${ }^{121}$ Private parties should not be penalized for legal activity. They relied upon existing law and the risks associated with changes in future laws to determine what to do. ${ }^{121}$ Retroactive legislation is often a tool of tyranny. Judging from the subsequent litigation history, these cases have not spawned serious impediments to regulation of business, ${ }^{122}$ while possibly deterring governments from passing oppressively retroactive laws. Of course, that deterrent benefit (assuming it is a benefit) is impossible to measure. Advocates of Spannaus will claim the lack of litigation demonstrates the doctrine's popularity and effectiveness, while opponents will dismiss the case as trivial and/or dangerous. Finally, liberals who fear a cataclysmic revival of Lochner-like jurisprudence from such cases should be less concerned if their representatives control a future Court.

\section{Ensuing Litigation}

Malleable factor and balancing tests tend to generate the most subsequent litigation. ${ }^{123}$ There will be arguments over applications of the standard(s) and/or over the terms of the test. In National League of Cities $\%$. Usery, ${ }^{124}$ thenJustice Rehnquist created a multiple factor balancing test to determine when Congress could regulate the "State as State." with "integral governmental functions" afforded their citizens,"

\footnotetext{
${ }^{119}$ The Constitution explicitly proscribes ex post facto laws, See U.S. Cons. art. 1, $₫ 9$, cl. 3. This presumption against retroactivity is further enshrined in the Contract Clause of Art. $1, \$ 10$, the Fifth Amendment's Takings Clause and in the fair notice mandates of the Due Process Clause. Landgraf $v$. USI Film Product, 511 U.S. 244, 266 (1994).

120) See, e.g., Oliver W. Holmes, Jr., The Path of the Law, 10 HARV. L. REv. 457, 477 (1897).

121 See United States Trust Co., 431 U.S. at 19 n.17 ("[C]ontracting parties adopt the terms of their batgain in reliance on the law in effect at the time the agreement is reached"); Spannaus, 438 U.S. at 245 .

122 See G. Richard Shell, Contracts in the Modern Court, 81 CAL. L. REV. 433, 436.

123 While there is an absence of empirical studies on the matter, many scholars support this supposition. See, e.g., A.C. Pritchard \& Todd J. Zywicki, Finding the Constitution: An Economii Analysis of Tradition's Role in Constitutional Interpretation, 77 N.C. L. Rev. 409, 495 n.368 (1999); Richard C. Ausness, Learned Intermediaries and Sophisticated Users: Encouraging the Use of Intermediaries to Transmit Product Safety Information, 46 SYRACUSE L. REV. 1185, 1236 (1996).

124426 U.S. 833 (1976).

${ }^{125} \mathrm{Id}$. at 842,854 .

${ }^{126} \mathrm{Id}$. at 855 .

${ }^{127} \mathrm{Id}$. at 851 .
}

(2011) J. JURIS 345 
TIIE JOURNAJ JURISPRUDENCE

function," "128 particularly when Congress displaces the States' freedom to "structure integral operations." ${ }^{\prime 29}$ States then challenged numerous federal laws and regulations. The lower courts tried to determine if States were engaging in a "traditional" function. ${ }^{130}$ Things did not get any clearer after Justice Marshall subsequently added another obscure criterion: Congress had to threaten an "attribute" of State sovereignty. ${ }^{131}$ Notice how it is easier for the Court to add or delete a factor from factor tests than to formally repudiate the doctrine. ${ }^{1.32}$ After a few years, the lower courts generated such a hodge-podge of outcomes that Justice Blackmun, who had originally concurred in Usery, overturned Usery in Garia v. San Antonio Metropolitan Transit Authority. ${ }^{13.3}$ He believed the resulting doctrinal chaos demonstrated that the Court could not create judicially manageable standards to protect the States. Nem York v. United States would be the first of several cases proving him wrong; conservatives found more workable doctrine.

Constitutional doctrine may evolve from a dynamic, indeterminate balancing test into a narrow, rigid rule designed to preclude future growth. For example, after advocates for the poor convinced a majority to require states to waive court fees in divorce cases in Boddie $\%$. Connecticut ${ }^{134}$, a future conservative majority, in Kras $v$. United States, limited Boddie to its facts. ${ }^{135}$ The Justices concluded that divorce, unlike bankruptcy, is a unique civil law remedy and is an aspect of the right to marry, which is protected by substantive due process. ${ }^{136}$ Kras was one of many cases eradicating the hope that the Supreme Court would create many positive rights assisting the indigent. ${ }^{137}$ There was one later exception: a bare majority held that children of illegal immigrants had a right to minimal, equal public education. ${ }^{138}$ But the other cases did not extend

\footnotetext{
${ }^{128} I$ d. at 852 (quoting Fry v. United States, 421 U.S. 542, 547 (1975).

${ }^{129} \mathrm{Id}$.

130 The lack of coherence and determinacy in District Courts precipitated Usery's eventual reversal. See Garia v. San Antonio Metro. Transit Authority, 469 U.S. 528, 538-39 (1985) (collecting cases).

131 Hodel v. Virg. Surface Min. \& Reclamation Ass'n, 452 U.S. 264, $287-88$ (1981).

132 Conservatives have attempted to eliminate "divisiveness" from the Lemon test in Establishment Clause jurisprudence. See Lynch v. Donnelly, 465 U.S. 668, 684 (1984). Justice Breyer recently revived the doctrine. See Van Orden v. Perry, 545 U.S. 677, 704 (2005) (Breyer, J., concurring).

133469 U.S. 528 (1985).

134401 U.S. 371 (1971).

135 United States v. Kras, 409 U.S. 434 (1973).

${ }_{136}$ Id. at $443-45$.

137 See, e.g., Dandridge v. Williams, 397 U.S. 471, 487 (1970) (welfare); Lindsey v. Normet, 405 U.S. 56 (1972) (housing); San Antonio Independent School Dist. v. Rodriguez, 411 U.S. 1 (1973) (equal funding of education).

138 Plyler v. Doe, 457 U.S. 202 (1982).
}

(2011) J. JURIS 346 
the educational right to require either free textbooks ${ }^{139}$ or transportation. ${ }^{140}$ This is one of the saddest areas of constitutional law. The nation's treatment of the poor and the working class (and now, more and more of the middle class) has been deplorable. Yet, the Court cannot easily use constitutional law to solve most problems in our political economy, much less the basic question of distributive justice. Keynes, Milton Friedman, or Herbert Spencer ought not to play a major role in constitutional adjudication. Unelected judges should not direct economies or wage wars; they do not have the "power of the purse" and "the power of the sword." Equally disturbing, the Court takes a core power from Congress by increasing expenditures without representation. Such moves entangle the Court in partisan politics and inevitably generate peculiar results, such as Lochner's permitting States to regulate miners' hours but not bakers' hours. What do unelected lawyers know about physical labor? Finally, State Court intervention has not been very effective: the Ohio Supreme Court found a state school funding plan to be unconstitutional in $1997,{ }^{141}$ but that decision, much heralded at the time, has sporadically influenced subsequent allocation of educational resources. ${ }^{142}$ What, ultimately, can the Ohio Supreme Court do? Hold the legislators in contempt if they fail to implement a particular funding scheme that the Court divined out of general constitutional text?

Justices face a dilemma that perpetually undermines their attempt to create enduring constitutional law. To justify any opinion, they must provide reasons and supporting facts. Yet every reason can become a requirement, and every fact can limit a decision's impact. Rehnquist's reasons in Usery became factors in subsequent cases, eventually leading to doctrinal chaos (according to Justice Blackmun). More recently, Justice O'Connor held that the Ohio could create a voucher system in the dysfunctional Cleveland public school system, partially because a pre-existing charter school system provided parents and students with many options. Are such facts constitutional perquisites, or can healthy school districts, which provide no alternatives, also use vouchers? In a similar fashion, Chief Justice Roberts refused to permit a city to use race to allocate students for integration purposes, noting that the program had not been used very often. Would this observation make a heavily utilized program constitutional? Fact-rich and reason-rich opinions resemble balancing tests, providing future Courts with alternative ways to distinguish or limit their authority without formally overruling them.

\footnotetext{
${ }^{139}$ Carnes v. Kentucky, 538 F.2d 328 (1976), cert. denied, 429 U.S. 1049 (1977).

${ }^{140}$ Kadrmas v. Dickinson Pub. Sch., 487 U.S. 450 (1988).

${ }^{141}$ DeRolph v. Ohio, 678 N.E.2d 866 (Ohio 1997).

142 See Shadya Yazback, Note, School Financing in Ohio Yesterday, Today and Tomorrow: Searching for a "Thorough and Efficient" System of Public Schools, 57 CASE W. RES. L. REv. $671(2007)$.
}

(2011) J. JURTS 347 
There are several normative reasons why most lawyers and Justices believe stare decisis is an important constitutional consideration. The doctrine promotes "the rule of law," stabilizes the culture, and contains the norm of temporal equality. But is worth remembering that stare decisis does not carry as much weight in constitutional cases as in statutory cases, because, except for in a few rare situations such as issues involving the "dormant commerce clause," only the Court can change its doctrine (except through the cumbersome amendment process).

\section{A. Enhancing "The Rule of Law"}

Until now, this article has have emphasized the "internals" of a doctrine, objective factors gleaned from the face of judicial opinions. It is time to address the underlying normative questions that have been somewhat begged: why take stare decisis seriously, especially when it compromises one's preferred conception of rights that also should be taken seriously? Perhaps Justices should quickly change constitutional law. If I agree with John Rawls that every citizen should obtain basic necessities, what not constitutionalize that right? ${ }^{143}$ In addition, stare decisis requires a Justice to discard Ronald Dworkin's vividly inspiring, but flawed metaphor of "rights as trumps." 144 If rights are trumps, then the lowliest right (which could be the constitutional equivalent of the "two of clubs" in terms of value) must prevail over all other interests (unless we consider some of those competing governmental concerns to be higher trumps, which ruins the analogy). ${ }^{145}$ Even if one has a constitutional right to bear arms and to one's property, it does not follow that one has a right to a Stinger Missile or to raise pigs in a suburban backyard. Not every component in property's "bundle of rights" deserves unlimited constitutional protection.

The most important counterargument to rapid constitutional change is that stare decisis promotes the "rule of law." 146 Justice Roberts emphasized this theme in his concurrence in Citizens United. Although some believe think the

143 This point is essentially captured in Rawls' "difference principle," which ensures access to necessities. See John Rawls, A THEORY OF Justice 137-40 (Harvard Univ. Press 1999) (1971).

144 Ronald Dworkin, Rights as Trumps, in THEORIES OF RIGIITS 152, 153 (Jeremy Waldron ed., Oxford Univ. Press) (1984) (" $[R]$ ights are best understood as trumps over some background justification for political decisions that states a goal for the community as a whole").

${ }^{145}$ For a recent critique of the "trumps" metaphor, see Richard H. Pildes, Why Rights Are Not Trumps: Social Meanings, Expressive Harms and Constitutionalism, 27 J. LEGAL STUD. 725 (1998).

146 See Roscoe Pound, What of Stare Decisis?, 10 FordLam L. R匹V. 1, 5 (1941) "Some conception of stare decisis is vital to the concept of limited government and the rule of law by restricting judicial 'absolutism."”); Lewis F. Powell, Jr., Stare Decisis and Judicial Restraint, 47 WASH. \& LEE L. REV. 271, 288 (1990).

(2011) J. JURIS 348 
notion of "the rule of law" is silly, vacuous, or misleading propaganda, ${ }^{147}$ it is a vital adhesive. ${ }^{148}$ The incomparable philosopher David Hume observed that the greatest human failing is our tendency to think short term. ${ }^{149}$ Relying upon force and persuasion, the legal system is the primary social institution for imposing a broader, lengthier perspective. ${ }^{150}$ Not only does it punish many forms of instant gratification (such as murder, fraud, or certain forms of drug addiction), but it also creates a cadre of professionals who benefit from enforcing the society's perceived long-term values. Aristotle refuted Plato's ideal of a static legal culture. ${ }^{151}$ We do not want a static legal system that is unresponsive to change and correction, but we also should fear an overly fluid system that disorients the citizenry and undermines the habit of legal obedience. $^{152}$ Just as the Court ought to apply a presumption of constitutionality to every law, every citizen should presumptively obey every legal mandate. In other words, stare decisis creates a "habit of obedience" for Justices.

Constitutional law plays an unusually large role in American law, politics, and culture for several reasons. The Constitution is the populace's primary symbolic source of allegiance, their legal Grundnorm. ${ }^{153}$ The Constitution also provides a collection of "secondary rules" establishing basic rule-generating and ruleenforcing procedures and institutions. ${ }^{154}$ Finally, the Supreme Court has applied the Constitution to a vast range of issues. But our country is not just run by an elite group of lawyers. Because there is an enduring tension between the electoral many and the judicial few, a whiff of illegitimacy lingers around every Supreme Court finding of unconstitutionality: why should five unelected, highly successful lawyers tell the rest of us what we can and cannot do in a country

${ }^{147}$ Felix Cohen disparaged "tules of law" as legal concepts within a "special branch of the science of transcendental nonsense." Transcendental Nonsense and the Functional Approach, 35 COLUM. L. REV. 809, 821 (1935).

148 See generally Brian Z. TAMAANAHA, ON THE RULE OF LAW: History, POLITICS, THEORY (2004); Brian Z. Tamanaha, How an Instrumental Viem of Law Corrodes the Rule of Lam, 56 DEPAUL L. REV. 469 (2007).

149 David HumE, A Treatise or Human NaturE 481 (BiblioBazaar 2007) (1739-40).

150) Id. at 481-83.

151 "Even when laws have been written down, they ought not always to remain unaltered . . Hence we infer that sometimes and in certain cases laws may be changed ..." ARTISTOLE, PoLITICS, Book II, Part VIII.

${ }^{152}$ Id. ("For the habit of lightly changing the laws is an evil, and, when the advantage is small, some errors both of lawgivers and rulers had better be left; the citizen will not gain so much by making the change as he will lose by the habit of disobedience."); see also THOMAS AQUINAS, Summa TheologicA, Question 97 "Of Change in Laws" (1274).

153 See generally, Hans KELSEN, GENERAL ThEORY OF THE LAW AND STate (Anders Wedberg trans., Harvard Univ. Press) (1945).

${ }^{154}$ For example, Art. 1, $\$ 9$, cl. 2 specifies the procedure by which a bill becomes law.

(2011) J. JURIS 349 
that is allegedly "democratic?" Efforts to distinguish the Court's actions as "legal" instead of "political" or "principled" rather than "policy driven" fail because all judicial determinations require some "political" viewpoint that first determines a law's purposes and next predicts how alternative choices of action may facilitate those ends. ${ }^{155}$ Every "principle" is ultimately justified by its value to the polity. The Justices need to persuade a large percentage of us that they are properly exercising (or refusing to exercise) their coercive powers. ${ }^{156}$ Fortunately for the Court, it need not rely on persuasion alone: the outcome, backed by force, is at least as important. Once the police enforce a particular doctrine, it gains some authority through acquiescence and habit. Lawyers master the Panglossian art of turning the "real" into the "reasonable."

The written opinion forces the Court to be somewhat transparent. The Court must present reasons and outcomes that are acceptable to a significant degree of the public (most cases, of course, are primarily of professional interest). ${ }^{157}$ That process limits judicial discretion/activism to an important degree: no Justice would write today that Brown $v$. Board of Education should be overruled because African-Americans are innately inferior. Stare decisis constrains the Court by requiring it to explain how its recent results coexist with its past. ${ }^{158}$ It is a major part of the common law method that requires a Justice to assess a problem from several different perspectives before reaching a final conclusion. ${ }^{159}$ The Justice revisits initial, intuitive reactions several times before making a final determination. When the Court avoids this discipline, it undermines the persuasive strength of not only the particular opinion, but also the Court itself. For instance-to use a "liberal" victory for a change-Justice Kennedy's opinion in Romer $v$. Evans ${ }^{160}$ was bewildering partially because he made no effort to explain why homosexuals deserved constitutional protection

\footnotetext{
155 This article disagrees with the claim that "precedent rarely influences" the decisions of Supreme Court justices. See Harold J. SpaEth \& JefFrey A. Secial, Majority Rule or MinORITY WILL: ADHERENCI TO PRECEDENT ON THE SUPREME COURT 287 (1999).

156 The Court's institutional legitimacy is considerably more robust than some of its decisions, see Richard H. Fallon, Legitimayy and the Constitution, 118 HARV. L. REV. 1787 (2005)

157 See Martin Shapiro, Law and Politics in the Supreme Court: New Approaches to Political Jurisprudence 29 (1964) .

158 Accordingly, stare decisis is arguably a better instrument for facilitating judicial restraint than conservative ideologies such as originalism. See Thomas W. Merrill, Originalism, Stare Decisis and the Promotion of Judicial Restraint, 22 CONST. COMMENT. 271 (2005).

15) Cf. Richard B. Cappalli, At the Point of Decision: The Common Law's Advantage Over Civil Law, 12 TEMP. INT’L \& COMP. L.J. 87 (1998); see also Lon L. Fuller, Reason and Fiat in Case Law, 59 HARV. L. REV. 376 (1946).

160) 517 U.S. 620 (1996).
}

(2011) J. JURIS 350 
after an earlier Court had held that States could criminalize homosexual behavior in Bowers v. Hardwick. ${ }^{161}$

\section{B. Maintaining Social, Political, and Legal Stability}

Stare decisis is an inherently conservative doctrine. ${ }^{162}$ The values of legal stability and obedience are particularly important in this country. It borders on using intellectual clichés to point out that the Constitution and the legal system play crucial roles in unifying American society, and that the people of the United States do not a common heritage. Perpetual immigration is one of the nation's defining characteristics. ${ }^{163}$ Americans live under an abstract system selfconsciously created by a few extraordinary statesmen instead of under a State that emerged out of (or was imposed upon) a culture existing for over a thousand years. Indeed, they have a notoriously bad historical memory, which is a curse (due to resulting ignorance and stupidity) and a blessing (because historical grudges tend to fade more quickly than elsewhere). ${ }^{164}$ Consequently, Americans across the political spectrum have a powerful interest in maintaining their belief in the "rule of law," even if that belief is somewhat fanciful, even mythological. ${ }^{165}$

Stare decisis serves this goal by reducing the Court's visibility (if the Court does not change existing law, fewer people notice). It requires the Court to engage in legal craftwork that simultaneously obscures and clarifies its reasoning, keeping many potentially divisive issues out of sight and thus out of mind. ${ }^{166}$ The Court should not dramatically change its law after every election and every new appointment, avoiding the impression that constitutional law is just another form of partisan politics.

161478 U.S. 186 (1986). The striking absence of a citation to Bowers in Justice Kennedy's opinion has been highlighted by virtually every scholar dissecting the Romer decision. See, e.g., Lynn A. Baker, The Missing Pages of the Majority Opinion in Romer v. Evans, 68 U. CoLO. L. REv. 387,389 (1997).

162 Craig Haney, Psychology and Legal Change: On the Limits of a Factual Jurisprudence, 4 LAW \& HuM. B匹HAV. 147, 159-60 (1980).

16.3 See generally Roger Daniels, Coming to America: A History of Immigration and Ethnicity in American Life (Harper Perennial) (2002).

164 A fundamental question is whether this epoch of relative calm in American politics is coming to an end.

165 See PaUl L. KAHN, American Exceptionalism, Popular Sovereignty, and the Rule of Law, in AMERICAN EXCEPTIONALISM AND HUMAN RigHTS 198, 198 (Michael Ignatieff ed., 2005) (arguing that the Constitution "produces the absolute bedrock of the American political myth: the rule of law is the rule of the people").

166 See Lawrence M. Friedman, Legal Rutes and the Process of Social Change, 19 STAN. L. REV. 786, $811(1967)$.

(2011) J. JURIS 351 


\section{Distinguishing the Facts}

A strong commitment to stare decisis reduces the overall stakes. It also puts pressure on the Court to make less disruptive compromises. Both Chief Justice Roberts' and Justice Alito's Senate confirmation hearings contained a great deal of discussion about the role of stare decisis; the two jurists reassured the nation that it would not see a new Constitution over the next few years. ${ }^{167}$ So far, with the notable exception of Citizens United, they have not engaged in the radical transformation that Justice Thomas seeks. ${ }^{168}$

The two new Justices demonstrated the value of stare decisis and the art of judicial distinction-making in the almost ludicrous case, Morse v. Frederick. ${ }^{169}$ A high school suspended a student for displaying a large banner on which he had written "Bong Hits 4 Jesus" while students gathered outside the school to observe the running of the Olympic Torch. ${ }^{170}$ The Justices were unsure what the banner meant. Although it is always difficult to determine Stoners' Intentions, one plausible interpretation is that a group of high school students were smoking marijuana when one of them observed that their pipe-passing was a sacrament, similar to communion. ${ }^{171}$ Surrounded by Christian Fundamentalists who had significantly different viewpoints about almost everything, they thought it would be funny to claim they were getting high on behalf of Jesus. This plausible interpretation complicates the issue. On the one hand, it supports the majority's belief that the banner was advocating the use of illegal drugs and wasn't pure gibberish. ${ }^{172}$ On the other, it suggests that the

\footnotetext{
${ }^{167}$ In the context of the Court's abortion jurisprudence, Roberts responded that "'a precedent of the court, like any other precedent of the court, [is] entitled to respect under principles of stare decisis." See Robin Toner, Court in Transition: Abortion; In Complex Dance, Roberts Pays Tribute to Years of Precedent Behind Roe v. Wade, N.Y. TiMes, Sept. 14, 2005, at A24. Justice Alito paid similar homage to the doctrine of stare decisis, proclaiming it to be "a very important doctrine" that is "a fundamental part of our legal system." Court in Transition; 'When a Precedent Is Reaffirmed, That Strengthens the Precedent', N.Y. TIMLS, Jan. 11, 2006, at A26.

168 Justice Scalia has been quoted as saying that Justice Thomas "doesn't believe in stare decisis, period" and "if a constitutional line of authority is wrong, he would say "let's get it right." See KEN Foskett, Judiang; Thomas: THE LifE and Times of ClarEnce Thomas 281-82 (2004). Nevertheless, Justice Thomas does apply the doctrine of stare decisis where it is presumably inopportune or imprudent to question longstanding Court doctrine. See Troxel $v$. Granville, 530 U.S. 57, 80 (2000) (Thomas, J., concurring).

169 127 S. Ct. 2618 (2007).

${ }^{170} \mathrm{Id}$. at 2622 .

171 The entheogenic use of marijuana has ancient origins. See Ernest L. Abel, Marijuana - The First Twelue-Thousand Years (1980), available at http://www.druglibrary.org/schaffer/hemp/history/first12000/abel.htm.

172 Morse, 127 S. Ct. at 2625.
}

(2011) J. JURIS 352 
students may also have been punished for blasphemy, an unconstitutional form of "viewpoint discrimination."

Rather than limiting himself to ancient constitutional history, Chief Justice Roberts cited evidence showing the damaging effects of illegal drugs on young people. ${ }^{173} \mathrm{He}$ argued that the high school had a legitimate interest in preventing students from displaying pro-drug symbols. This makes sense: high school students should not wear shirts to school endorsing various illegal vices or even glorifying such legal vices as drinking, smoking, and gambling. There is no total suppression: they can change clothes once they leave. Roberts distinguished the case from Tinker, ${ }^{174}$ which had protected a student's right to wear a black armband to school to protest the Viet Nam War, because political debate over decisions to go to war should be part of one's education, unlike the advocacy of illegal drugs. ${ }^{175}$ Of course, this distinction is crudely circular, because advocacy of illegal drug usage all but explicitly includes the political message of legalization.

Nevertheless, many high school parents want their children to think about when this nation should fight abroad, but far fewer wish for their children to be surrounded at school by peers celebrating the consumption of illegal substances. In his concurrence, Justice Thomas wanted to overrule Tinker, asserting that public high schools could impose whatever constraints on speech they wish. ${ }^{176}$ Roberts's scalpel is preferable to Thomas's sledgehammer. High schools should be a place of intellectual and political diversity. We don't want public school officials to have the power to impose total orthodoxy. There have been very few examples of distuption caused by students wearing campaign buttons $^{177}$ or crosses to school. Students benefit from exposure to and expression of different political and religious viewpoints. But there is an immediate cost if many children feel peer pressure, seemingly tolerated by the authorities, to experiment with drugs that range from problematic to fatal. Some forms of viewpoint discrimination are permissible in high school ${ }^{178}$ (very few liberals would argue that public schools should not promote such norms as diversity, decency, and environmentalism).

\footnotetext{
173 Morse, 127 S. Ct. at 2628.

174 Tinker v. Des Moines Independent Community School Dist., 393 U.S. 503 (1969).

175 Morse, 127 S. Ct. at 2629.

$176127 \mathrm{~S}$. Ct. at $2633-35$.

177 Cf. Chandler v. McMinnille Sch. Dist., 978 F.2d 524, 530 (9th Cir. 1992) (holding that student buttons containing the pejorative word "scab" were not inherently disruptive).

178 Even the dissent in Morse concedes this contention; " $[\mathrm{I}] \mathrm{t}$ might well be appropriate to tolerate some targeted viewpoint discrimination in this unique setting." $127 \mathrm{~S}$. Ct. at 2646 (Stevens, J., dissenting)..
}

(2011) J. JURTS 353 


\section{Constitutional Prudence}

Stare decisis diminishes the likelihood of rapid intellectual revolutions sweeping through the Court. Linked to the past by doctrine and habit, Justices learn a degree of judicial humility, ${ }^{179}$ a trait these powerful, unelected officials with lifetime tenure desperately need. Not only should they defer somewhat to "the Framers" and "the People" who originally created the Constitutional text, but they also should respect the prior adjudicators who wrestled with the same issues. First impressions and reactions are often the best. The great conservative theorists Edmund Burke and Michael Oakeshott feared the dangers of excessive rationalism, a blend of excessive confidence in one's particular ideology, indifference to the existing culture, and elevation of abstract theory over facts and history. ${ }^{180}$ Many modern conservatives have been as guilty of such intellectual hubris as the liberals on the Warren Court-one need only contemplate the baneful effects of market fundamentalism, ${ }^{181}$ rigid Originalism, a conception of the "unitary Executive" elevating the Presidency above the law, ${ }^{182}$ and permissive antitrust doctrine that helps create and protect massive corporations which then become "too powerful to fail." "183 While intellectual fads have more endurance than the average person's pursuit of pleasure, they often are transient forces, products of intellectual arrogance and economic interests. One decade, Milton Friedman's belief in the wisdom of market equilibrium frames the debate, while the next era may prefer John Maynard Keynes' embrace of uncertainty and wealth redistribution. It is risky when doctrinaire movements grab effective control of the economy and the political process, much less when they gain enduring influence through the less flexible, less democratic process of constitutional adjudication. When most people obtain power, they often believe the world has suddenly become a much better and saner place. They perceive a mandate to implement most of their views. ${ }^{184}$ Thomas Aquinas explained that rulers must be prudent, not trying to change

179) See Daniel A. Farber, The Rule of Law and the Law of Precedents, 90 MINN. L. REV. 1173, 1178 (2006).

180 This is what Burke describes as the "abuse of reason." See EDMUND BURKE, A VINDICATION OF NATURAL SOCIETY (Liberty Fund Inc. 1982) (1757); see also EDMUND BURKI, REILECTIONS ON THE REVOLUTION IN FRANCE passim (Oxford Univ. Press 1999) (1790); Michazl OAKESHOTt, Rationalism in Politics and Other Essays (Liberty Fund Inc. 1991) (1962). Stare decisis is very Burkean-asserting the need for continuity, humility, and respect for the past at the expense of abstract theory.

181 See, e.g., Milton Friedman, Capitalism and Freedom (1962); Friedrich Hayek, Individualism and Economic Order (1948).

182 See Steven G. Calabresi \& Kevin H. Rhodes, The Structural Constitution: Unitary Executive, Plural Judiciary, 105 HARV. L. REV. 1153 (1992).

18.3 See Adam Nguyan \& Matt Watkins, Financial Services Reform, 37 HARV. J. ON LEGIS. 579, 590 $(2000)$.

(2011) J. JURIS 354 
habits too quickly. ${ }^{185}$ For example, it would be a cultural and legal disaster to outlaw cigarettes, despite their obvious dangers and the venality of their purveyors.

Liberals are equally attracted to the dangerous charms of philosophical consistency. The Supreme Court might have blundered if it had forced busing into Detroit suburbs to address segregation in the City. ${ }^{186}$ The majority's arguments may not have been the best: ${ }^{187}$ what "principled" distinction can be drawn between Milliken's protection of the suburbs and an earlier opinion finding pervasive discrimination within a school district based due to limited discrimination within the district? ${ }^{188}$ Everyone knows that the suburbs, agents of the State, were zoned to keep out undesirables. ${ }^{189}$ State-designed systems of multiple municipalities facilitated and perpetuated segregation and undermined integration. But blasting apart the suburbs may have done more harm than good to race relations and the gradual emancipation of African-Americans: black middle class flight soon followed white flight. ${ }^{190}$

There is an understandable and justifiable tendency for liberals on and off the Court to take a great deal of credit for President Obama's remarkable electoral achievement; but it is likely that the conservatives' restraining hand also contributed to his victory by blunting the liberals' understandable desire to aggressively achieve racial justice. Although it is arguably too late for the Courts to dramatically improve race relations through constitutional law, plaintiffs should have focused on quality and/or "equal" neighborhood schools rather than busing. Admittedly, that doctrine would have turned the Courts into virtual school boards, but it arguably would have been warranted in light of the nature and extent of the underlying constitutional injustice.

Justice Frankfurter and Judge Learned Hand criticized excessive judicial review. ${ }^{191}$ If elite lawyers resolve most important, divisive issues, the polity becomes passive. In addition, extensive judicial review distorts the electorate's decision-making, enabling factions to combine into oddly shaped political

\footnotetext{
185 THOMAS AQUINAS, SUMMa THEOLOGiCA, Question 97 "Of Change in Laws" (1274).

${ }^{186}$ Milliken v. Bradley, 418 U.S. 717 (1974).

187 See Robert L. Carter, Public School Desegregation: A Contemporary Analysis, 37 ST. LoUIS U. L.J. 885,890 (1993).

${ }^{188}$ Keyes v. School District, 413 U.S. 189 (1973).

189 See, e.g., Clement E. Vose, Caucasians Only: the Supreme Court, the NAACP, and the Restrictive Covenant Cases 1-28 (1967).

${ }^{190}$ See generally Mary Jo Wiggins, Race, Class, and Suburbia: The Modern Black Suburb as a 'Race-Making Situation,' 35 U. MIC.H. J.L. REForM 749 (2002).

191 See W. Va. State Bd. of Educ. v. Barnette, 319 U.S. 624, 668 (1943) (Frankfurter, J., dissenting); see also LTARNED HAND, THE BILL OF RIGHTS 73-74 (1958).
}

(2011) J. JURIS 355 
parties. The Warren Court's enthusiastic protection of many constitutional rights enabled libertarians and social conservatives to combine within the Republican Party; libertarians did not have to worry about a significant loss of individual rights so long as the Court remained somewhat "liberal." Judicial deference forces Americans to confront serious problems. The Court may have injured the Democratic Party permitting some affirmative action, thereby alienating many white voters, but at least the electorate has the last word in terms of higher education. ${ }^{192}$

\section{Temporal Equality}

Stare decisis promotes "fairness." "193 Conservative Justices did not jettison most of the Warren Court's jurisprudence: they embraced cases like Brown and Brandenburg $^{197}$ and extended the Warren Court's egalitarianism to gender equality $^{195}$ and, to a lesser degree, gay rights. ${ }^{196}$ Consistency is an often overlooked egalitarian norm, which we can call "temporal equality." Liberals perceive themselves as more committed to equality than their political rivalsstare decisis reminds everyone that there is a presumptive fairness in deciding similar cases in similar ways over relatively long periods of time. The Supreme Court can ignore or repudiate any doctrine under the "changed circumstances" test, but it should not employ that tool frequently. ${ }^{197}$ After all, many problems have not changed: the struggle between the few and the many, man's inhumanity to man, the need for safety, the destruction of the environment, and the value of self-expression (just to name a few of the values and conflicts that have absorbed humans for thousands of years). Citizens feel particularly degraded when they are informed that they have lost rights or powers after relying upon a prior decision because new Justices believe times have changed. $^{198}$ Finally, and more prosaically, constitutional stability reduces

192 Daniel Patrick Tokaji, Note, The Persistence of Prejudice: Process- Based Theory and the Retroaactivity of the Civil Rights Act of 1991, 103 YALE L.J. 567, 584-86.

193 The notion that the Court should not discard precedent merely because of changes in personnel has been described as an "argument from fairness." See Frederick Schauer, Precedent, 39 STAN. L. REV. 571, 595-97 (1987).

${ }^{194}$ Brandenburg ». Obio, 395 U.S. 444 (1969).

195 See, e.g., Craig v. Boren, 429 U.S. 190 (1976) (settling on intermediate scrutiny for gender classifications).

196 See, e.g., Lawrence v. Texas, 539 U.S. 558 (2003).

197 See State Oil Co. v. Khan, 522 U.S. 3, 20 (1997) (" [S]tare decisis is not an inexorable command ... there is a competing interest, well represented in this Court's decisions, in recognizing and adapting to changed circumstances.") (citations omitted).

198 Cf. Monaghan, supra note —, at 749-50 ("Expectations, tangible and symbolic, have developed around the critical decisions; massive destabilization following a successful attack on any of these would threaten the functioning of the federal government, if not the viability of the constitutional order itself.").

(2011) J. JURIS 356 
transaction costs. ${ }^{199}$ Lawyers, potential litigants, governmental officials, and lower courts can rely upon existing doctrine. ${ }^{200}$

Despite its many values, Stare decisis is just one of several constitutional variables. Most of us acknowledge the need for flexibility and adaptability. ${ }^{201}$ If the Court followed Plato and never changed prior doctrine, the country would be strangled by rules that few people would support. When the Justices took their judicial oath, they vowed to support the Constitution, not the Court's prior opinions. ${ }^{202}$ Prior adjudications are constitutional derivatives, worthy of limited deference. Ultimately, stare decisis should not be taken too seriously.

\section{Normative, Divisive Factors}

The prior descriptive and normative factors are always part of the stare decisis calculation, but they often are dwarfed by competing ideological considerations triggered by a particular issue. While the legal profession constantly argues about proper modes of interpretation (whether and how to use text, history, structure, purpose, and so forth) and applications of those modes to particular texts and fact patterns, political passion underlies abstract arguments and frequently arcane historical interpretations.

\section{A. Controversy and Importance}

Justices never overturn a decision simply because of the vote count. Nor do they always uphold cases to create stability and foster obedience. At best, those considerations intimate that the Justices should only overrule "dreadful" cases, those that are perceived by many people (lawyers, academics, politicians, and, in major cases, the laity) to be unacceptable. Preferably, with major cases, the critics should represent many political perspectives, not just a narrow group of party activists and intelligentsia.

No Court explored the role of stare decisis with more directly than the plurality in Planned Parenthood of Southeastern Pennsylvania v. Casey. ${ }^{203}$ The three Justices refused to overrule a woman's "core right" to have an abortion during the earlier stages of pregnancy, because that right was the "essential holding" of the

${ }^{199}$ Farber, supra note —, at 1177.

200 Jonathan R. Macey, The Intemal and External Costs and Benefits of Stare Decisis, 65 CHI.KTINT L. REV. 93, 102 (1989).

201 Hence, Justice Brandeis famous admonition that "[s]tare decisis is not . . a universal inexorable command." Burnett v. Colorado Oil \& Gas Co., 285 U.S. 393, 405 (1932) (Brandeis, J., dissenting).

202 See 28 U.S.C. $\$ 453(2006)$.

203505 U.S. 833 (1992).

(2011) J. JURIS 357 
incredibly controversial Roe $v$. Wade. ${ }^{204}$ They listed the normal stare decisis considerations-- practical workability, reliance, consequences, abandoned doctrine, and changes in either the facts or the interpretation of the facts ${ }^{205}$ but next emphasized that some cases are special, because the Court had "responded to national controversies." "116 The Justices found two analogues to the abortion controversy in the Twentieth Century: the Supreme Court's repudiation of Lochner $v$. New York's applying substantive due process to economic regulation and Brown's invalidation of Plessy v. Ferguson's "separate but equal" public school systems. ${ }^{207}$

There is no self-evident way to ascertain which cases fall within this category; each Justice must calibrate the importance of the issue and the degree of public reaction. But the Casey plurality undoubtedly reviewed three deeply divisive, important issues that bedevil the nation: the appropriate degree of economic regulation, race relations, and family structures. The plurality explained that it had reconfigured economic and racial constitutional law because "society" had a newer and better "understanding of the facts."208 Somehow, the Court became "society." Although that move seems presumptuous, it is necessary whenever the Court revisits its most important holdings. The Court is more justified in invoking "society" when it reduces judicial review, as in Locbner, than when it second-guesses the legislature, as in Brown and Roe/Casey. Legislative action also reflects social understandings. Still, the pluality properly pointed out that stare decisi plays a different role when the stakes are very high. Quite simply, the bigger the constitutional stakes, the harder the fall. When it comes to the less important cases, the Court can more easily overrule "bad decisions" because few will notice or care. The Court also can engage in the usual tradecraft of isolating and distinguishing prior cases to the point of "abandonment." ${ }^{\text {"209 }}$ It does not matter that much whether or not States have certain constitutional immunities ${ }^{210}$ or individuals have a right to pass out campaign materials at private shopping centers. ${ }^{211}$ To put it bluntly, a lot of constitutional law is not very significant. But there is no subtle way to eliminate

\footnotetext{
204 Id. at 846.

${ }^{205}$ Id. at $854-55$.

206 Id. at 861.

${ }^{2017}$ Id. at $861-63$.

${ }^{2018}$ Id. at 862-63.

20\% See Lawrence B. Solum, The Supreme Court in Bondage: Constitutional Stare Decisis, Legal Formalism and the Future of Unenumerated Rights, 9 U. PA. J. CONST. L. 155, 191-92 (2006). 210 See, e.g., Hans v. Louisiana, 134 U.S. 1 (1890) (holding that the Eleventh Amendment immunizes states from citizen suits in federal court); Seminole Tribe of Florida v. Florida, 517 U.S. 44 (1996) (holding that the commerce clause of Article 1 does not vest Congress with the power to abrogate state sovereign immunity). I would reconsider this highly activist doctrine. 211 Pruneyard Shopping Center v. Robins, 447 U.S. 74 (1980)
}

(2011) J. JURIS 358 
segregated schools: either the Court overrules Plessy or perpetuates that cruel, divisive educational system.

Conversely, there is a cluster of cases that the Court will probably not revisit because of their perceived effectiveness. They are known as "superprecedents." Many of them are structural, allocating governmental powers. Most law students begin their constitutional studies with Marbury $\nu$. Madison and McCulloch \%. Maryland, because those cases fleshed out much of the Constitution's textual structure.

\section{B. The "Fit" Between Doctrine and Text}

In Philosophical Investigations, Wittgenstein explained how everyone, including Supreme Court Justices, uses language as a "game." 213 Words cannot be applied or understood in isolation. They gain their particular meaning from the function they play within any particular language "game."214 For instance, we don't know what the word "strike" means until we ascertain its functions in such different "games" as bowling, baseball, lighting a cigarette, criminal law, and labor law. Each clause within the Constitution creates its own "game," creating a subset of technical doctrine: "fundamental rights" differ under the two Privileges and Immunities clauses, ${ }^{215}$ "Substantive Due Process," ${ }^{216}$ Equal Protection, and the First Amendment. Wittgenstein then observed that we utilize exemplars to illuminate and justify interpretations. ${ }^{217}$ Invoking Professor Hart's famous example, a court interprets the prohibition against a "vehicle in the park" ${ }^{\prime 218}$ by determining that ordinance's purposes (which in turn requires us to determine the consequences the law was trying to encourage and prevent) and by considering a particular situation that many (hopefully most) of us would consider a clear violation, such as a drunk who plowed his truck through the park's flowerbed. If we disagree on "easy cases," it will be hard to move forward. Eventually, particular cases create "core rights" and "core powers" that are supported by "core examples." Almost by definition, these decisions will be harder to overrule than peripheral instances. For example, it would be

212 See Michael J. Gerhardt, Super Precedent, 90 MINN. L. REV. 1204 (2006).

21.3 WITTGENSTLIN, supra note , at $5 \mathrm{e}$, Aphorism 7.

${ }^{214} I d$. at $6 \mathrm{e}, 109 \mathrm{e}$, Aphorisms 11,340 ,

215 Slaughter-House Cases, 83 U.S. 36 (1873); see also Saen₹ v. Roe, 526 U.S. 489 (1999) (right to travel under the Privileges or Immunities clause of the Fourteenth Amendment).

216 See, e.g., Griswold v. Connecticut, 381 U.S. 479 (1965) (right to contraception); Roe v. Wade, 410 U.S. 113 (1973) (right to abortion); Loving v. Virginia, 388 U.S. 1 (1967) (right to heterosexual marriage).

217 Wittgenstein, supra note at 34e, Aphorism 71.

${ }^{218}$ Hart first proffered the heuristic in Positivism and the Separation of Lans and Morals, 71 HARV. L. REV. 593, 607 (1958).

(2011) J. JURIS 359 
far more disturbing if the Supreme Court eliminated Brandenburg $\%$. Obio's vitally important incitement test, which both on its face and as applied created the judicial ban on viewpoint discrimination against particular political ideologies, than if the Court no longer protected lap dancing or internet obscenity. Just as Justices evaluate statutes to determine how well their chosen means serve legislative ends, so Justices reevaluate prior Supreme Court opinions to determine how well they "fit" with a particular constitutional text's purposes.

Although it would take at least a law review to develop the points made in the prior paragraph, R.A.V. v. St. Pau ${ }^{19}$ provides a good example of Wittgenstein's methodology in action. Although the liberal wing concurred in the judgment, the case has remained notorious because it prevented the criminalization of "hate speech."220 Just like Justice Kennedy in Romer, Justice Scalia reconstrued the challenged statute so many times that it became a straw statute. But Scalia's straw statute was worth burning down. According to Scalia, the law was onesided, applicable only to white racists and other politically incorrect segments of our society, not to those whom the City believed had been historically oppressed. $^{221}$ R.A.V. fits well into the existing First Amendment doctrinal universe by reinforcing the core right of "political speech" doctrine" of viewpoint discrimination, ${ }^{22.3}$ both of which advance the First Amendment's primary goal of protecting robust debate so the people can make informed political and personal decisions. ${ }^{224}$ Although there are risks in allowing racists to express themselves, there are greater dangers of political oppression, distortion of the electoral process, and damage to individual autonomy if the State can criminalize one side's arguments. ${ }^{225}$

R.A.V. also gains strength because it is difficult to design a better alternative. The inability to come up with a better approach is a major indication that a particular law or legal doctrine is "well-tailored." The concurring liberals believed that the defendants' speech could be suppressed under a better drafted

\footnotetext{
219505 U.S. 377 (1992).

220) See, e.g., Cass R. Sunstein, Words, Conduct, Caste, 60 U. CHI. L. REV. 795, 822-33 (1993); Akhil Reed Amar, The Case of the Missing Amendments: R.A.V. v. City of St. Paul, 106 HARv. L. Riv. 124 (1992) (arguing that Reconstruction Amendments may provide a constitutional home for "hate speech" statutes).

221 R.A.V., 505 U.S. at 391-92

222 Morse, $127 \mathrm{~S}$. Ct. at 2626 ("Political speech, of course, is 'at the core of what the First Amendment is designed to protect." (quoting Virginia v. Black, 538 U.S. 343, 365 (2003)).

${ }^{22.3}$ Perry Educ. Ass'n v. Perry Local Educators' Ass'n, 460 U.S. 37, 59 (Brennan, J., dissenting).

224 See POPPER, supra note

225 See generally Steven G. Gey, The Case Against Postmodern Censorship Theory, 145 U. P^. L. REV. 193 (1996).
}

(2011) J. JURIS 360 
statute falling within the "fighting words" exception. ${ }^{226}$ But Scalia had a telling response: the State's power to ban fighting words does not include the lesser power to ban a subset of politically unpopular fighting words. ${ }^{227}$ The liberals' position seemed to permit the government to ban obscene movies that criticize the government. ${ }^{228}$ Finally, general laws proscribing harassment, threat, and assault have worked reasonably well in preventing the spread and damage of hate speech.

\section{Purposes and Consequences}

Aristotle perceived that prediction was a major rhetorical tool. Political and legal advocates assert that their solution better serves a particular society's chosen ambitions. ${ }^{229}$ They also warn of catastrophic consequences should they lose. Justices on the Supreme Court often foretell cataclysmic results if their views do not prevail. Every lawyer has used the "slippery slope:" the immediate issue may be close, but ruling against my client will create a dangerous precedent. ${ }^{230}$ To some degree, the Court can rely upon "the test of time" to determine which of its earlier prophets were right or if the decision generated unintended consequences. To paraphrase Karl Popper's description of the scientific method, ${ }^{231}$ the Court makes doctrinal propositions that may be refuted by subsequent events. Of course, the scientific analogy does not carry very far. There are no double blinds in constitutional law: we cannot rerun opinions to see what would have happened if the Court had acted differently. Causation is often attenuated; we cannot be sure how the Court's doctrine influenced culture over time. Verification also fluctuates depending upon the nature of the issue and the outcome of the case. If the case is a relatively unimportant component of constitutional law, it will be difficult to demonstrate its overall effect on society. Conversely, should the case be a "watershed" decision, central to our culture, it will be difficult to determine what would have happened if the decision had gone the other way. For example, it is possible

${ }^{226}$ R.A.V., 505 U.S. at 413-15 (White, J., concurring) (invalidating the statute on the grounds that it had applied the fighting words doctrine too broadly).

227 Id. at 386-88. In his concurrence, Justice White accuses Justice Scalia of creating an "underbreadth" doctrine. Id. at 402.

$228 \mathrm{Id}$. at 388 .

229 See ARIsTOTLE, 1 Rhetoric, reprinted in THE COMPLETE WORKS OF ARISTOTLE 2160 (Jonathan Barnes ed. \& J.O. Urmson trans., 1984).

230 "Slippery slope" arguments have been dissected and discussed in great detail in legal scholarship. See, e.g., Frederick Schauer, Slippery Slopes, 99 HARV. L. R๘V. 361 (1985); see also Eric Lode, Slippery Slope Arguments and Legal Reasoning, 87 CAL. L. R匹V. 1469 (1999); Eugene Volokh, The Mechanisms of the Slippery Slope, 116 HARV. L. R匹V. 1026 (2003).

231 See Conjectures and Refutations: The Growth of Scientific Knowledge (Routledge Classics 2002) (1963).

(2011) J. JURIS 361 
that Gerald Rosenberg and Derrick Bell correctly concluded Brown was insignificant ${ }^{232}$ or counterproductive, ${ }^{233}$ but we fortunately never will be able to verify those claims. More fundamentally, legal "prediction" or "refutation" invariably consists primarily of normative assessments of subsequent events and of public reactions, placing the entire inquiry in the land of "ought" instead of Popper's scientific world of "is." There will be no consensus over the consequences, even assuming a causal link between legal doctrine and cultural evolution. Roe's defenders point to positive changes in family life, particularly increased female autonomy. But for some of Roe's critics, that change is another deplorable aspect of the opinion.

Whenever the Court determines a law be unconstitutional, it is harder to determine the costs and benefits of the original law. We are cut off from many subsequent facts that would help us determine if the Court or the legislature had initially acted properly. The legislature no longer can gather evidence to justify its law. This empirical obstacle is yet another reason for a presumption of constitutionality. For instance, when the Court held that the death penalty was not a cruel and unusual punishment, ${ }^{234}$ the Nation has continued to wrestle with the issue. The public and the legislature will determine if the death penalty should be used aggressively against convicted murderers, limited to massive terrorist attacks, or eliminated. There are plenty of statistics and chilling anecdotes to support both positions. More recently, the Court refused to prevent a city from aggressively using eminent domain power. ${ }^{235}$ Responding to an angry electorate, many States passed laws or constitutional amendments limiting that power. Thus, the issue remained in the public domain, where all of us can study which approach works better. Federalism's experimentalism flourishes under a regime of judicial restraint.

\section{Changed Circumstances}

The Casey plurality emphasized two versions of the "changed circumstances" test: the Court can change law when it discovers new facts (Chief Justice Warren wrote that prior generations did not understand how segregation injured black children) $)^{236}$ or it develops a "new understanding" of pre-existing facts. ${ }^{237}$ These two formulations can be misleading; because they make the

232 See Gerald N. Rosenberg, The Hollow Hope: Can Courts Bring About Social Change? (Univ. of Chicago Press) (2008).

${ }^{233}$ Derrick A. Bell, Silent Covenants, Brown \%. Board of Education and the Unfulfilled Hopes for Racial Reform (2004).

${ }^{234}$ Gregg v. Georgia, 428 U.S. 153 (1976).

${ }^{235}$ Kelo v. City of New London, 545 U.S. 469 (2005).

236 Brown v. Board of Education, 347 U.S. 483, 494-95 (1954).

237505 U.S. at 854-55.

(2011) J. JURIS 362 
Supreme Court look merely ignorant when sometimes it also may have been venal (it is often impossible to determine when a person or institution is acting as a fool, a knave, or both). For example, there are several ways to view Plessy: (1) The Court did not know what was going on; (2) The Justices drew the "wrong" inferences from the facts; (3) New developments demonstrate that they had an inadequate data base; (4) Subsequent developments inspire different jurisprudential perspectives creating a different set of inferences; and/or (5) The majority understood the facts and accepted the outcome. Both Brown and Casey placed their predecessors in the first four categories: the Locbner jurists had not lived through the Depression, which undercut, at least for a while, the allure of market fundamentalism, ${ }^{238}$ while the Plessy Court was unaware of modern sociological findings. ${ }^{239}$ Furthermore, the Court and American society had evolved and learned from its past "mistakes." But Justice Harlan's stirring dissent in Plessy ${ }^{2+0}$ reminds us that the Plessy majority grasped the moral, political, and legal implications of Southern apartheid. ${ }^{241}$ That Court apparently did not care, supported the suppression of blacks, or felt impotent in light of foreseeable backlash. In a similar vein, the Lochner Justices understood the competing economic philosophies, preferring laissez faire and deregulation over the belief in unequal bargaining power between labor and capital, which they saw as an unconstitutional purpose. The Casey approach demonstrates the Court's extraordinary discretion. If five Justices on the Court conclude that "society" has determined that the "facts" have changed, then the challenged opinion is truly history.

\section{E. Stare Decisis and Two Forms of "Judicial Restraint"}

Zelman $v$. Simmons-Harris ${ }^{2+2}$ culminated a long campaign by judicial conservatives to reinterpret the First Amendment to permit school vouchers for private religious schools. Another example of formal equality, Zelman can be broadly interpreted to hold that States can distribute vouchers to private religious schools so long as they do not discriminate among religions nor discriminate in favor of religions. ${ }^{243}$ Many opponents believed this holding would devastate

${ }^{238}$ Casey, 505 U.S. at 861-62.

${ }^{239} \mathrm{Id}$. at 863 .

240) 163 U.S. 537, 552-64 (1896).

${ }^{241}$ Cf. id. at 557 (Harlan, J., dissenting) ("Every one knows that the statute in question had its origin in the purpose, not so much to exclude white persons from railroad cars occupied by blacks, as to exclude colored people from coaches occupied by or assigned to white persons."). 242536 U.S. 639 (2002).

${ }^{243}$ Zelman, 536 U.S. at 662 (emphasizing that the Ohio program was "entirely neutral with respect to religion").

(2011) J. JURIS 363 
inner city school systems, ${ }^{244}$ while advocates argued that it would provide parents, particularly inner city parents, with more options and put needed competitive pressure on often corrupt, inadequate public school systems. ${ }^{245} \mathrm{By}$ lifting the pre-existing constitutional ban, the judicial conservatives allowed the electorate the opportunity to assess the costs and benefits of vouchers. So far, the change has not yet been profound. Very few school systems have implemented a voucher system. ${ }^{246}$ Where vouchers have been permitted, many parents have chosen to remain in the public school system. The results of increased privatization have been mixed: some children have obtained access to superior educational opportunities, ${ }^{247}$ while others have become exploited by private schools primarily designed to enrich their founders. ${ }^{248}$ The fight is bitter and political. Not all voucher advocates are primarily concerned about children: many simply want to reduce taxes. On the other hand, many opponents are interested in keeping public school jobs and tenure. In short, both sides have strong constitutional and policy arguments. That constitutional doubt warrants keeping the voucher issue in the political domain so the experiment can continue.

Stare decisis's presumption of continuity creates a different conception of "judicial restraint" than the presumption of constitutionality, which restrains the Court from invalidating actions of other governmental entities chosen by the electorate. Stare decisis restrains Justices from overruling their predecessor's actions, not from overruling the actions of other parts of the government. Thus, stare decisis can perpetuate prior antimajoritarian judicial activism as well as prior judicial restraint. On the other hand, doctrinal stability reduces the Court's visibility, because rival factions do not expect as much out of the Court in the future and because less happens during the present. Usually, stare decisis works below the surface: the Justices simply refuse to grant certiorari. ${ }^{249} \mathrm{By}$ helping keep the Court out of the political limelight, stare decisis preserves the image of the Court as a "legal" institution rather than a political one. Any strict distinction between law and politics approaches the absurd, because all legal

${ }^{244}$ See Charles Fried, Five to Four: Reflections on the School Voucher Case, 116 HARv. L. REv. 163, 168 (2002).

${ }^{245}$ See Michael Leo Owens, Why Blacks Support Voubers, N.Y. Tim匹s, Feb. 26, 2002, at A25.

246 As of fall 2007, only twelve school voucher programs had been implemented in the United States. Patrick J. Wolf, School Voucher Programs: What the Research Says About Parental School Choice, 2008 B.Y.U. L. REV. 415, 417 (2008).

${ }^{247}$ Wolf, supra note , at 435 .

${ }^{248}$ See, e.g., Bruce Lieberman, Clock is Ticking for TIP Academy: Charter School Has Until Friday to Answer Conflict Allegations, SAN DiEGo UNION-TriB., May 25, 2008, at B1.

24) See Michael J. Gerhardt, The Role of Precedent in Constitutional Decisionmaking and Theory, 60 GEO. WASH. L. REV. 68, 78 (1991) (arguing that "precedents perform a crucial role in constitutional decisionmaking by framing the Court's decisions on whether to grant certiorari").

(2011) J. JURIS 364 
decisions are a form of political/practical reasoning, of choosing between competing interests. Nevertheless, Americans need to believe that they live under a "rule of law" as well as a "rule of politics." The Constitution, the Court, and the legal/political system would lose a great deal of adhesive power if Justices bluntly said that they decided a certain case to benefit the supporters of the political party that selected them in the first place. ${ }^{250}$ Humans coexist by engaging in "willful suspension of disbelief," partially believing in and being dazzled by a Wizard of Oz's pyrotechnics while also knowing that a regular person pulled levers somewhere behind all the gloss. Major cases invariably tend to strip away the useful fiction of the law/politics distinction. ${ }^{251}$ It is hard to take the legal arguments in Bush \%. Gore $e^{252}$ very seriously when every Justice found an argument that supported the Presidential nominee most likely to appoint similar Justices to the Supreme Court, and every Floridian official proposed a solution that benefited their Party. Does anyone really believe that the case would have gone the same way if it had been entitled Gore v. Bush?

\section{F. Reliance, Rights, and Structures}

While bad facts are said to make bad law, difficult cases often generate clumsy arguments. In Casey, the plurality shifted the justification for the abortion right away from Roe's emphasis on medical autonomy to concerns over bodily integrity and a woman's right to family planning. ${ }^{253}$ However, that welcome move was accompanied by the claim that it protected women's "reliance" interests. ${ }^{254}$ At first blush, "reliance" seems an odd metaphorical doctrine, because the Court was protecting future abortions. ${ }^{255}$ To use Fuller and Purdue's famous contract distinction ${ }^{256}$, the Court actually protected an

250 See Casey, 505 U.S. at 865-66 (O'Connor, J., plurality opinion).

251 The law/politics dichotomy helps maintain the legitimacy of the Court and, consequently, is an interpretive example of Lon Fuller's "legal fictions." LON L. FULLER, LEGAL FICTIONS (1967). It is a "meta-legal fiction." Fictions are "not intended to deceive" and serve an invaluable emotive function in "induc[ing] conviction that a given legal result is just and proper." Id. at 6, 54 .

252531 U.S. 98 (2000).

${ }^{253}$ Compare Roe, 410 U.S. at 153 (framing a women's decision as a part of her relationship with her physician) and Casey, 505 U.S. at 857 (conceptualizing Roe as an exemplar of liberty "decisions about whether or not to beget or bear a child" as well as "a rule . . of personal autonomy and bodily integrity.")

254 Casey, 505 U.S. at 856.

255 The plurality acknowledges that the use of the term "reliance" may appear inapposite, "except on the assumption that no intercourse would have occurred but for Roe's holding, such behavior may appear to justify no reliance claim." Id. at 856.

${ }^{256}$ Lon L. Fuller \& William R. Perdue, Jr., The Reliance Interest in Contract Damages, 46 YALI L.J. 52, 54 (1936).

(2011) J. JURIS 365 
"expectancy" interest. Reliance protects prior decisions. ${ }^{257}$ Even the Casey Court agreed that reliance is more applicable to the "commercial context." 258 The Court partially escaped this confusion by noting that it was perpetuating part of a culture that Roe helped create by making it much easier for "women to participate equally in the economic and social life of the Nation.. ${ }^{259}$ This broad conception of "cultural reliance" applies to any contentious, important case. All law helps establish underlying culture. ${ }^{2(1)}$ Southern whites relied upon their superior status during the segregation era, but that "reliance" interest is despicable.

To the degree that "reliance" is a legitimating factor, it should be more applicable to "rights" cases than to "structure" cases, which distribute public power. Vulnerable and emotional, individuals have a greater need for continuity; they can be emotionally and even physically damaged by constitutional change. Bureaucracies adapt more easily to redistributions in power than emotional individuals. If one looks at the public reaction to recent constitutional decisions, most citizens care far more about rights cases than structure cases. ${ }^{261}$ Admittedly, the categories overlap. Expanding state immunities against tort suits under the Eleventh Amendment involves both structures and rights. But those cases, which stripped millions of people of a crucial damage remedy, have generated little public debate compared to such issues as affirmative action, school prayer, and abortion. Thus, a pure structural case, such as I.N.S. v. Chadha ${ }^{262}$ or New York v. United States, has a lesser claim to stability than a mixed case or a pure individual rights case.

Nor should all rights cases be given equal stare decisis weight. Some rights protect actions that have little or no effect on other people, "innocent delights" ${ }^{963}$ that easily satisfy John Stuart Mill's libertarian principle protecting people from state regulation so long as they do not injure anyone else. ${ }^{264}$ Because there is no conflicting interests (unlike abortion and affirmative action), there is little reason to revisit the Court's recent protection of gay

${ }^{257}$ Id.

258 Casey, 505 U.S. at 855.

${ }^{259} \mathrm{Id}$.

260 Martha Minow, Not Only For Myscle: Identity, Politics, and the LaW 102-104 (1997).

261 This is reflected in the news coverage, which emphasizes individual rights cases. Ethan Katch, The Supreme Court Beat: How Television Covers the U.S. Supreme Court, 67 JUdICATURE 1, 10 (1983).

262462 U.S. 919 (1983).

26.3 John Locke, Two Treatises of Government; and a Letter Concerning Toleration 155-56 (Ian Shapiro \& John Dunn eds., Yale Univ. Press 2003) (1690).

264 John Stuart Mill, On Liberty 21-22 (1859).

(2011) J. JURIS 366 
sexuality in Lamrence. Criminal procedure falls in the middle of this libertarian spectrum: on the one hand, procedural rights protect all individuals from the state; conversely, those rights make it harder to punish victims' perpetrators. Other rights, such as the right to an abortion and the right not to be racially discriminated against by affirmative action, are zero-sum games. It is not surprising that these issues generate the most heat. Overall, the Court should be most willing to reconsider any case that prevents the legislative branch from dealing with intractable, enduring political conflicts.

\section{G. Judicial Theory, Partisan Politics, and Public Opinion}

There must be a moment when all sitting Justices size up a new member to determine which prior decisions may now be narrowed, abandoned, or even overruled. Chief Justice Rehnquist quickly moved to overrule a death penalty case after David Souter joined the Court. ${ }^{265}$ Rehnquist explained that the prior cases were decided by a five-to-four margin containing "spirited dissents." Since then, more and more dissents aspire to be "spirited." In Justice Scalia's case, most of his dissents are not just spirited, but also acerbic. The "spirited" adjective raises both methodological and normative concerns. How are we to determine when an opinion is "spirited?" Also, this factor encourages shrill opinions, undermining internal institutional cohesiveness, reducing public civility before an already polarized citizenry, and dissolving the useful myth that law is a profession of principle, not just a reflection of contemporary partisan conflict.

On the other hand, passions, some hot and some cooler, animate every outcome. As Holmes famously said, "law is the felt necessities of the times." 267 In other words, law consists of emotions transformed into power. Anger distorts, but also inspires. Justice Scalia's dissents make unpleasant reading for many, but they are peppered with sardonic wit and insight. Thus, a "spirited dissent" immediately serves several purposes. Merely by existing, it becomes a legally acceptable ground for reversal. It sends a signal to losing lawyers that they may eventually prevail if political fate provides additional sympathetic Justices. Depending upon the stakes, the Justice also appeals to the broader community, particularly his or her political allies. Justice Scalia bitterly claimed that Lawrence's legalization of homosexual behavior was a liberal victory in the "Culture Wars." ${ }^{268}$ More recently, Justice Breyer read an angry dissent from the

265 Payne v. Tennessee, 501 U.S. 808 (1991), overnuling Booth v. Maryland, 482 U.S. 496 (1987) and South Carolina v. Gathers, 490 U.S. 805 (1989).

${ }^{260}$ Payne, 501 U.S. at 828-29.

${ }^{267}$ Holmes, supra note _, at 477.

268539 U.S. at 602 (Scalia, J., dissenting).

(2011) J. JURIS 367 
bench in Parents Involved to emphasize his despair at the majority's unwillingness to permit cities to implement integration programs at public schools. ${ }^{269}$ Professor Guinier subsequently showed how community organizers have used Breyer's dissent for political as well as legal purposes. ${ }^{270}$

\section{Public Opinion}

While few Supreme Court decisions capture the public imagination, most never register. At best, they spend a day on the front page of the New York Times. For example, it is unlikely that many people are aware of Parents Involved (although many more know and care about Heller's and McDonald's protection of firearms under the Second Amendment). Nor has there been much outrage over the partial birth abortion decision. It is not easy to predict public reactions. Many people, including Justice Blackmun, were surprised about the widespread, continual hatred of Roe after the mild response to Griswolds protection of contraceptives. ${ }^{271}$ More often than not, judicial restraint is met with more favor because it less disruptive and validates pre-existing governmental and popular preferences already filtered through the electoral process. Although the Burger Court was not as conservative as some would have wished, it made a series of decisions protecting suburban, middle-class lifestyle. States were under no constitutional obligation to integrate suburban schools via busing ${ }^{272}$ or suburban neighborhoods via housing. ${ }^{273}$ Nor need suburbs share their wealth with inner city schools. ${ }^{274}$ Mall owners could protect their shoppers from distracting political protesters. ${ }^{275}$ Plaintiffs could not prove racist intent in housing or jobs requirements simply because a facially neutral law had a disparate effect on minorities. ${ }^{276}$ All these constitutional compromises may or may not be justifiable under many progressive moral theories or interpretive methods, but the best reason not to revisit them is that they reflect Aquinas's observation that rulers should prudently operate within a particular society's constraints. Aggressively reconfiguring suburban life would embitter millions of citizens who would have little or no immediate political recourse.

269) Oral Opinion of Justice Breyer, Parents Involved in Community Schools \%. Seattle School Dist. 127 S. Ct. 2738 (2007), available at http:// www.oyez.org/cases/20002009/2006/2006_05_908/opinion

270 Lani Guinier, Foreward: Demosprudence Through Dissent, 122 HARV. L. RLV. 4 (2008).

271 See Linda Greenhouse, Becoming Justice Blackmun: Harry Blackmun's Supreme Court Journey 135-39 (2006).

${ }^{272}$ Milliken v. Bradley, 418 U.S. 717 (1974).

${ }^{273}$ Lindsey w. Normet, 405 U.S. 56 (1972).

274 San Antonio Independent School Dist. v. Rodriguez, 411 U.S. 1 (1973).

${ }^{275}$ Lloyd Corp. v. Tanner, 407 U.S. 551 (1972).

${ }^{276}$ W ashington v. Davis, 426 U.S. 229 (1976).

(2011) J. JURIS 368 
2. Stare Decisis and Legal Theory

After the public has initially reacted to a particular case, debate over most issues shifts to the elite: lawyers, law professors, business leaders, economists, political scientists, governmental officials, and so forth. At that point, interested opinion leaders propose theories to rationalize or attack particular opinions, trying to create a coherent pattern out of the somewhat random process of constitutional adjudication. After Edwin Meese retired from serving as United States Attorney General, he inspired the conservative "originalist" movement. ${ }^{277}$ Owen Fiss proposed "antisubordination" as a major normative standard. $^{278}$ John Hart Ely recommended a more process-based approach policing the democratic process. To the degree that these visions continue to attract attention and support, they become another way to appraise prior Supreme Court opinions, another substantive stare decisis criterion. Continuing popularity among the intelligentsia establishes legitimacy.

For example, no decision was more politically provocative in recent years than Bush $\%$. Gore, when five Justices determined who should be President. Although the actual outcome was very debatable - the Court should have remanded the Court back to the recalcitrant Florida Supreme Court with clear directions for counting ballots so the voters would have the "last word"-Bush v. Gore's underlying rule of "equal voting procedures" coexists with the three theories mentioned above. First, one can reasonably assume that the Framers wanted all eligible votes to be counted the same way. Next, voters who have their vote excluded in one precinct but not in another are subordinated to voters living in laxer regions. All voters are also oppressed by election officials, who have excessive discretion. Third, equal electoral standards reinforce Ely's belief that the Court's primary obligation is "representation reinforcement," the protection of the democratic process. ${ }^{279}$ More generally, formally equal standards reduce corruption, increase accuracy, legitimate the system, and are inherently fair. Future liberals should not overrule Bush $\nu$. Gore; they should expand it. ${ }^{280}$ For example, they could hold that the constitution requires a paper trail for every major election to monitor compliance.

277 See Johnathan George O'Neill, Originalism in American Law and Politics: A Constitutional History 133-61(2005).

278 Owen M. Fiss, Groups and the Equal Protection Clause, 5 PHIL. \& PUB. AFFAIRS 107 (1976). Fiss designated the standard as the "group-disadvantaging principle."

${ }^{279}$ Ely, supra note —, at 88.

${ }^{280}$ Cf. Adam Liptak, Bush v. Gore Set to Outlast Its Beneficiary, N.Y. TimLs, Dec. 23, 2008, at A1.

(2011) J. JURIS 369 
a. Originalism

Over the past few years, constitutional scholars have focused on the role of originalism in constitutional interpretation. The continuing endurance of this methodological formalism, which looks only to the "original understanding" of a text, is puzzling to some of us. Its persistence demonstrates that the quantity and quality of supporters, on and off the Court, can be as important as anything else. Over twenty years ago, Professor Powell assembled massive evidence supporting his conclusion that the Framers were not Originalists. ${ }^{281}$ Thus, to be an Originalist meant not following the Framer's jurisprudence. Furthermore, it is hard to determine what the Framers, much less the general populace, meant when they voted for a Constitution containing a multitude of clauses. It is difficult to remain a pure originalist, even within a single opinion. How can one reconcile Justice Scalia's claim in Heller that the Court should determine the "scope" of the Second Amendment by looking at the original understanding with his reassurance that citizens do not have a right to a machinegun or a sawed off shotgun because people "typically" do not keep such guns for "lawful purposes?" 282 How does he know? Isn't his definition of the right being largely determined by present customs, not ancient understandings? A sawed off shotgun resembles a blunderbuss. It would be handy if burglars entered one's home. In future years, many frightened homeowners might "typically" want such weapons.

But these technical problems are secondary. A serious commitment to Originalism (assuming one can find one "right," "clear" answer to so many contemporary questions in the scrolls of history) requires a massive dose of judicial activism: Justice Thomas doubts the constitutionality of the New Deal. ${ }^{283}$ Relentless Originalism threatens many important doctrines that most modern conservatives, who tend to be Originalism's warmest advocates, wish to retain: corporations currently have significant constitutional rights; the Federal Reserve Board is relatively autonomous and can print paper money; and public schools cannot segregate the races.

Some Originalists attempt to solve this activist problem by tolerating the constitutional status quo: stare decisis trumps Originalist findings. ${ }^{284}$ The Court should "sin no more," exclusively using Originalist approaches in the future.

${ }^{281}$ H. Jefferson Powell, The Original Understanding of Original Intent, 98 HARV. L. REV. 885 (1985).

282 Heller, 128 S.C. at 2815-16.

283 See, e.g., Loper, 514 U.S. at ___ (Thomas, J., concurring) .

${ }^{284}$ See, e.g., Richard Primus, When Should Original Meanings Matter, 107 MICH. L. REv. 165 (2008). Primus quotes Justice Scalia, who concluded that stare decisis was an "exception" to the requirement of originalist interpretation. ANIONIN SCALIA, A MATTER OF INTERPRETATION: FHIDHRA COUR'IS ANI 'IIIH, LAW 140 (Amy Gutmann ed., 1997).

(2011) J. JURIS 370 
Stare decisis has become a huge trump. But why shouldn't some prior decisions be overruled? Most Originalists would invalidate Roe $\%$ W Wade, the case that helped stimulate Originalism. Also, if there are good, real-world reasons to keep cases that do not fit into the Originalist straightjacket, those reasons should trump an abstract interpretive theory. If the Court ought to overrule Roe because it emerged out of the oxymoronic doctrine called "substantive due process," it seems the Court should also overrule Griswold s protection of the use of contraceptives and Bolling \%. Sharpe ${ }^{285}$ ban of racial segregation in the District of Columbia. There are many reasons to overrule or preserve Roe, but they extend far beyond the debate over interpretive method.

\section{b. Antisubordination and Anti-tyranny Principles}

As mentioned above, many liberals want to revive the "antisubordination" principle, which includes concerns about tyranny but questions many more injustices. ${ }^{286}$ While that principle has legislative value, I am wary of applying it rigorously at the constitutional level. It is rather obscure and disturbingly broad. Every State has a legal system that creates a hierarchy, which contains an element of subordination. Furthermore, the principle provides little guidance when rights collide. In Parents Involved, for instance, the white parents who wished to send their children to nearby schools were subordinated by school officials who wanted to place the children in less integrated schools. Admittedly, the parents had not endured the historical, systemic subordination of African-Americans, but they were coerced. The anti-subordination principle also forces the Court to readjust the nation's political economy. The poor and the working class have been among the most oppressed groups over the past few decades. Although it would be inspiring to reconfigure the Constitution to help fight the perpetual class war on behalf of the many, that struggle should primarily be fought within the elected branches.

The great conservative thinkers Edmund Burke and Michael Oakeshott feared political, economic, or legal theories that were highly abstract, celebrations of "reason." Such theoretical thinking, which often makes a fetish out of consistency, easily generates decisions that are out of touch with the body politic, which is hardly monist. The elite seduce themselves with their alleged "rationality." Reductionist thinking, whether interpretive or substantive, is particularly hard to apply to constitutional law. Each text in the Constitution provides a different set of interpretive problems, because each clause serves particular, sometimes conflicting purposes which may also conflict with other legitimate purposes served elsewhere in the Constitution).

285347 U.S. 497 (1954).

286 Siegel, supra note

(2011) J. JURIS 371 
Nevertheless, all of us use abstractions to regulate behavior. Our society sometimes strongly feels the need to create consistency by creating a general value/norm that is often described in the legal realm as a "principle." For instance, under the First Amendment, it is crucial to preserve "viewpoint discrimination" and slightly less strict scrutiny of "content discrimination." Consequently, liberals should not revisit Rosenberger $v$. Rector, ${ }^{287}$ which held that Universities had to provide any committed support to all student publications. The University of Virginia could not discriminate against those students who wrote about religion because they were engaging in a "religious activity," which was defined as any activity which "primarily promotes or manifests a particular belief in or about a deity or an ultimate reality." 288 The scheme had many problems. First, it was difficult to implement - can the University refuse to give money to atheist Marxists or Darwinists? ${ }^{289}$ Second, it discriminated against a cluster of beliefs, placing the "religious" below the "political," "cultural," or "artistic." And what is "ultimate reality" anyway? Finally, Rosenberger is worth retaining because it all but holds that blasphemy laws are unconstitutional. Incidentally, the religious students have a good argument that they were being subordinated.

Originalism is inherently stale, antisubordination excessively broad, and Ely's protection of the democratic process too narrow. Assuming Originalism, antisubordination, and representation reinforcement are useful, but insufficient interpretative tools, where else should the Court look? Most of us can find constitutional common ground via our opposition to tyranny. The Framers understood that tyranny can arise in many ways. ${ }^{291}$ While this article can only sketch the argument, the goal of "tyranny prevention" helps determine which constitutional issues are really important, which "fundamental rights" are more "fundamental" than others. The list of "core rights" arguably includes the rights to run for office and vote for political leaders ${ }^{292}$, to dissent, to assemble, to be

287515 U.S. 819 (1995).

288 Id. at 822.

${ }^{289}$ Id. at $836-37$.

${ }^{290}$ Id. at $831-32$.

${ }^{291}$ John Locke defined "tyranny" as "the exercise of power beyond right, which nobody can have a right to. And this is making use of the power one has in his hand, not for the good of those who are under it, but for his own private separate advantage." Locke, supra note —, at 188.

292 Although the fictional Justice Handy may not have been speaking for his creator, Lon Fuller, Handy argued there are only a few "fundamental rules of the game:" "the conduct of elections, the appointment of public officials, and the term during which an office is held." Lon Fuller, The Case of the Spelunchean Explorers, 62 HARV. L. REV. 616, 638 (1949). But Handy extended the notion of "fundamental rights" to protect the bizarre "free civilmoign system." Id. at 639. Fuller may have been ironically intimating that once a jurist extends the notion of "fundamental rights" beyond the basic electoral system, all bets are off.

(2011) J. JURIS 372 
safe from summary incarceration by the government, to not be a slave or live in an apartheid or virulently sexist system, to be protected from confiscation, and to live in a society that rejects any Divine Right of Presidents. After such initial applications of the general principle, "tyranny" may not provide much more guidance that "Natural Law." Some will say banning abortion is tyrannical; others will reply that killing a fetus is the shocking injustice. Noam Chomsky believes corporations are a form of private tyranny. ${ }^{29.3}$ Despite these problems, the prevention of tyranny is a reasonable place to stop the process of legal/political abstraction and make a constitutional stand, lest we spin into an infinite regress. There are many reasons to oppose tyranny in its myriad forms, but the core "reason" is a self-evident, intuitive value: "All men are created equal." ${ }^{294}$ While Americans disagree over many issues, few of us want to see the nation degenerate into tyranny. The abortion dispute will not go away, but most Americans oppose a Taliban-like culture that systemically degrades women. Returning to free speech doctrine, the "fit" between "viewpoint discrimination" doctrine and the "anti-tyranny" principle is very tight. It is hard for government officials to overwhelm political opponents as long as dissenters can openly express themselves and influence future elections.

If the prevention of tyranny is our primary constitutional concern, it is necessary to look all prior decisions, not just those won by conservative Justices. Stare decisis should not protect any tyrannical decisions. The principle uneasily coexists with Hamdi $v$. Rumsfeld, ${ }^{295}$ in which seven Justices permitted the government to incarcerate citizens without providing full Article III Court protections. Most importantly, alleged terrorists do not have a right to a jury, ${ }^{296}$ the institution that Jefferson called a "sacred palladium of liberty."297 The Trial $^{298}$ Josef $\mathrm{K}$ may end up with more procedural protections than those the Court eventually provides to alleged terrorists under the malleable Mathews $v$. Eldridge due process balancing test. ${ }^{299}$ The Obama administration's plan to assassinate American citizens who are suspected of terrorism (but not on a

293 See NoAm Chomsky, ChOMSky ON ANARChism 192 (2005); "Consent Without Consent": Reflections on the Theory and Practice of Democray, 44 CLEV. ST. L. REV. 415 (1996).

294 See The Declaration of Independence para. 2 (U.S. 1776).

295542 U.S. 507 (2004).

${ }^{296} \mathrm{Id}$. at 533 (O'Connor, J., plurality opinion) (only requiring "notice of the factual basis for his classification, and a fair opportunity to rebut the Government's factual assertions before a neutral decision maker"); contra id. at 570 (Scalia and Stevens, JJ.., dissenting).

297 Letter from Thomas Jefferson to James Madison, Dec. 20, 1787 in The Writings of Thomas Jefferson Vol. 6: Containing His Autobiography, Notes On Virginia, Parliamentary Manual, Official Papers, Messages And Addresses, And Other Writings, Official And Private 385-93 (Andrew A. Lipscomb ed.) (2007)

${ }^{298}$ Franz Kafka, The Trial (1925).

299424 U.S. 319,335 (1976).

(2011) J. JURIS 373 
battlefield) is another tyrannical development. ${ }^{310}$ Hamdi is the worst decision since Buckley v.Valeo" (Buckley and its progeny, Citizens United, involve the related problem of "corruption," which, if unchecked, is often a precursor to tyranny). Because Hamdi enables the government to round up citizens, it has the potential for great evil. If a citizen faces indefinite detention in a navy brig, most other constitutional rights are of little value. Hamdi falls within the important, "controversial" decisions that Casey wrestled with, even though Hamdi has not provoked much academic or public outrage. One can only hope that "new facts" or "new understanding of the facts" will someday lead to the burial of these woefully misguided decisions. Maybe widespread torture and murder will make the nation reevaluate Hamdi.

\section{c. Electoral Backlash}

Just as there can be "backlash" when the Court expands a right, as it did in $\mathrm{Roe}^{302}$ and Brown, ${ }^{303}$ there also can be public outrage when the Court contracts a right or makes other significant changes. ${ }^{304}$ Supreme Court Justices need to be prophets-guessing the likely impact of their decisions and public reactions. Once again, Aquinas' conception of prudence is salient: the Court needs to be wary of imposing too many of its imaginings on the populace. Every time the Court is judicially active, it regulates other officials who more directly represent the citizenry. In his famous article on judicial restraint, Professor Thayer described the art of judicial review as "that combination of a lawyer's rigor with a statesman's breadth of view." 3015 The Court is one of our society's managers; we only hope it can help steer the nation through its inevitable problems instead of adding to them.

The Court is not an Olympian institution. There is a more disturbing component of judicial forecasting that is rarely discussed, a factor Justices never include in their opinions even though it lurks about every controversial decision: sometimes, they should consider how a decision could influence future elections. Because it is absurdly easy to make conventionally acceptable constitutional arguments without including this troubling assessment, Justices will never admit to engaging in such a crass calculus. They probably would deny they even think about such things. Because powerful people have tremendous

300 Glen Greenwald, Confirmed:Obama authorizes assassination of U.S. Citizen, Salon, April 7. 2010 .

301424 U.S. 1 (1976).

302 See, e.g., Robert Post \& Reva Siegel, Roe Rage: Democratic Constitutionalism and Backlash.

303 See, e.g., Klarman, supra note

304 See Eskridge, Jr., supra note _, at 1314.

305 James B. Thayer, The Origin and Scope of the American Doctrine of Constitutional Lan, 7 HARV. L. REV. 129, 138 (1893).

(2011) J. JURIS 374 
capacities of self-rationalization, they may well persuade themselves of their virtue. There is no need to push this irrefutable (and thus unprovable) argument too far. Perhaps Justices don't think about future elections. Perhaps they are unaware, even at the unconscious level, of some powerful, rather obvious reasons why they might consider political as well as cultural consequences. But there is no reason for outsiders to be so proper. Even if one believes that the Court operates on a less sordid plane, one can obtain an illuminating perspective that seems to have a fair amount of predictive and analytical power, by analyzing the Court in terms of partisan politics. For example, whether intended or not, the conservatives rush in Citizens United to dramatically expand the role of corporate money in the 2010 election helped move both parties to the right, just as Buckley previously undercut the more progressive wing of the Democratic Party.

As Bush v. Gore demonstrated all too crudely, Justices have a strong interest (whether aware of it or not) in having new members of the Court who are sympathetic to their ideology. All Justices want to win future cases and not see their prior decisions reduced to footnotes. In other words, Justices do not just read election returns: they influence future elections and may make calculated forecasts. This creates another stare decisis problem when Justices reconsider a decision they probably would have initially rejected. The party faithful expect "their" Justices to champion many of their causes, yet too many victories in one direction enrages the opposition and expands its base (after Lawrence, it has become easier for libertarian gays to join the Republican Party). Supreme Court nominations are one of the great spoils of every Presidency. And Supreme Court decisions are the great spoils of the Court. Over time, a bloc of Justices rewards its allies more than its opponents. Thus, whatever else can be said about Heller and McDonald, it was a victory not just for the National Rifle Association, but also for every person who has a rifle in the back of a pickup truck. A future liberal majority should be very wary of revisiting Heller. Neither side of the Court has done much for rural white society and the working class over the past few decades. Once these voters no longer have to worry about their right to keep their rifles and pistols, many of them will be more open to progressive messages and more likely to vote for a party that would appoint more liberal Justices who would then support liberal statutory changes.

At least from the perspective of those who are not members of the Court, taking future elections into account is a valid normative criterion. I am more interesting in seeing the society become more humane than in seeing many of my preferred norms receive constitutional protection. Sometimes, it is preferable to trade off constitutional outcomes for electoral victories. Many of 
us would rather have progressive control of the elected branches than a federal constitutional right to a gay marriage (as important and as valid as that right is).

Justice O'Connor, the last Justice to win an election, had great instincts at creating doctrine and outcomes that resonated with much of the populace. Whether one looks at her overall work from the perspective of Thayer's "statesmanship" or from the political perspective of keeping moderate Republicanism in power (at least for many years), she created a constitutional settlement of many controversial issues that both sides should be wary of disturbing. There is a "core right" to an early abortion. Affirmative action is permissible only in higher education. Religious private schools are eligible for vouchers. Gays cannot be arrested. Sickly citizens have an obscure "right to die." If either side profoundly alters these doctrines, their corresponding political party may pay a high price. Elimination of the abortion right would anger many men and women. Eliminating vouchers would alienate inner city parents and those who wish to send their kids to religious schools. Recriminalization of gay sex would drive many more gays to the Democratic Party. Most senior citizens do not want to spend their last months or years in great pain or in a vegetative state (and many seniors live in the swing state of Florida). Preventing any form of affirmative action would influence the increasingly important Hispanic vote. Thus, future liberal Justices should tolerate the Court's determination that public schools, unlike Universities, could not use race as a factor in Parents Involved. Liberals should live with legislative constraints on late-term abortions, which are quite grisly and understandably upset many people. There will be plenty of new problems for future Justices to handle-the treatment of suspected terrorists and their captors will raise painful legal issues, such as whether victims of American torture should obtain damages. Hopefully, the Court will not permit the Executive branch to kill citizens without any trial. And there remain numerous technical issues, such as the scope of federalism and federal court jurisdiction, to provide fodder for the professionals.

It is probably naïve to hope for a constitutional cease-fire over the culture wars, but that is this article's recommendation. If Justices on both sides see judicial restraint toward precedent to be in interests of themselves, their party, and the nation, there is a better chance to resolve other important issues that have been ignored. But there is an important qualification. This approach is not a version of constitutional minimalism. Occasionally, the Court needs to be very aggressive, as in Brown. 


\section{H. Better Reasoning}

Justice Brandeis believed a case should be overturned whenever there is "better reasoning." 306 Because "better reasoning" contains any and all ideological assumptions, his recommendation goes too far. All majority opinions contain a cluster of reasons that were publicly acceptable when the case was decided, so no easy way exists to determine when a competing set of reasons is "better." Brandeis is almost suggesting there is a "right answer" to difficult constitutional issues. Whether one agrees with this article's normative recommendations or not, its compilation of stare decisis factors reveals how constitutional reasoning contains numerous considerations that cannot be reduced to a simple syllogism. If the Court revisited every case whenever five Justices thought they had better reasons than their predecessors, stare decisis would be a very thin reed. It is worth re-emphasizing that one of the functions of stare decisis is to encourage Justices to tolerate earlier decisions that they initially rejected (or would have dissented from had they been on the Bench). The legal realist Karl Llewellyn once wrote that every legal decision needs a "singing reason," a fit between justification and outcome that resonates with lawyers' informed intuition. ${ }^{307}$ The values served by stare decisis intimate that the Court should accept prior decisions even when they are quite out-of-tune. Good decisions should be retained and bad ones overruled, but tolerance ought to be shown to the merely ugly.

\section{Coda: Applying the Model to Citizens United}

Early in Justice Kennedy's Citizens United ${ }^{308}$ opinion creating a new right for unions, non-profit corporations, and all for-profit corporations to spend unlimited amounts of "independent" money from their general funds to support or oppose particular politicians, he claimed that stare decisis does not "compel" his slender majority of five Justices to abide by a contrary outcome, Austin $\%$. Michigan Chamber of Commerce", decided twenty years earlier. This article's catalogue of stare decisis variables demonstrates that stare decisis never compels anything. It is a norm that competes against other constitutional values; the very complexity and malleability of the doctrine confirms dissenting Justice Stevens' observation that policy considerations drive constitutional adjudication. ${ }^{310}$ While Kennedy and Stevens disagree on many levels, they focused on four stare variables: (1) the "workability" of the existing doctrine;

\footnotetext{
306 Bumet, 285 U.S. at 406-408 (1932) (dissenting opinion).

307 Karl Llewellyn, The Common Law Tradition 210-15, $493-96$ (1960).

308558 U.S. (2010).

309494 U.S. $652(1990)$.

310 Citizrens United, 558 at (Stevens, J., dissenting).

(2011) J. JURIS 377
} 
(2) the antiquity of the precedent; (3) the reliance interests created by the opinion; and (4) the quality of the challenged decision's reasoning. ${ }^{311}$ Justice Roberts' concurrence emphasized the amorphous, slightly romantic "rule of law." None of the Justices used the Casey methodology of first characterizing the issue as major and then determining if there has been a widespread cultural shift that undermines the prior decision. For anyone concerned about the increasing concentration of wealth and power in a few hands in this republic, Citizens United is a profoundly important opinion, similar to Lochner, Plessy, and Roe \%. Wade. And there is no consensus, on or off the Court, for giving corporations more power at the expense of average citizens. The ironically titled Citizens United diminishes the average citizen's power.

Citizens United relied heavily upon formal equality: citizens, individuals, and associations should have identical free speech rights. The Court observed that the challenged doctrine not only discriminates against certain associations, but it also favors media corporations over those corporations that do not have direct access to traditional forms of mass communication. The new, sweeping doctrine is admittedly more "workable." Congress will have less power and be less accountable for the corrosive role of money in politics: anyone can spend unlimited amounts of money to help elect anyone. The Courts will have less to do. Perhaps the majority will permit Congress to limit foreign corporations' spending, but its reasoning points in the opposite direction. Anyway, a clever foreign corporation can pad a contract with a friendly American corporation, which then can support sympathetic, grateful politicians. Under the prevailing rhetoric, politicians only provide "access" to their donors and are never "corrupted." Lochner should remind us that the attractively abstract and universal nature of formal equality often elevates intellectual and doctrinal purity above the inevitably grimy world of partisan and economic politics. Formal equality transcends time-ignoring past injustices, present imbalances, and future inequities. But this transcendentalism can glide over many of life's complexities. More pragmatically, the Austin approach proved workable: both the political and the legal system have not had much difficulty enforcing this limitation on corporations since it first appeared in $1907 .^{312}$

When Justice Scalia was often in a minority, he would invoke "tradition" to constrain liberal judicial activism. Now that he is part of a small majority that might evaporate if President Obama's election signifies a shift to the center or even to the left, Scalia and his colleagues focus on "the antiquity of the precedent." Their baseline is 1990, the date of Austin, not 1907, the year of the

${ }^{311} I d$. at _ and (Stevens, J., dissenting).

312 ABC News, In Supreme Court Ruling on Campaign Finance, the Public Dissents (Feb. 17, 2010).

(2011) J. JURIS 378 
first legislation conditioning corporate power. The majority described Austin as an anomaly, simply because nobody had previously thought there was a reasonable chance that the Court would so dramatically jump into the political thicket. Nor has there been widespread opposition to Austin, except in The Federalist Society and the Chamber of Commerce. Locbner interfered with legislative efforts to fight the Depression; Plessy legitimated southern apartheid; while Roe still provokes outrage. Austin has been the quiet target of the modern conservative intelligentsia; Justice Robert's confirmation odes to judicial restraint and precedent seem far less convincing. Most public opinion polls taken after Citizens United revealed widespread opposition across party lines: a Washington Post poll found eighty per cent disagreed with the Court. ${ }^{313}$

Kennedy next all but eliminated the "reliance" standard by equating it with contractual and property rights. ${ }^{314}$ Indeed, reliance is most useful when considering the constitutional status of common law rights. But we have already seen that reliance does not fully capture how Supreme Court helps rule our nation: there is a notion of "cultural reliance." Many decisions, such as Roe v. Wade, allocate power and rights that create cultural norms, traditions, and expectations that should not be quickly discarded. In terms of contract metaphors, there are also constitutional expectancy interests. For example, children should not be forced to attend racially segregated public schools. Do we preserve Brown because of "reliance?" We preserve it to protect all of our children's futures. We oppose racism because it is a pernicious force that divides and degrades everyone. Many of us want to reduce private power, which relies heavily but not exclusively upon the corporate form, to protect the Republic from instability caused by the weakening of the middle class and the degradation of the poor. We agree with Aristotle that republics become unstable when there the rich become too powerful or the poor too numerous and demoralized. We are not just preserving the past; we want to protect the future. Justice Scalia wailed when the Court entered into the "culture wars" by protecting homosexuality ${ }^{315}$, but eagerly wades into the class war that is more central and enduring. Overall, it is hard to take seriously all the "conservative" talk of Originalism, judicial restraint, and keeping the Court of politics.

Echoing Brandeis, Kennedy found Austin not "well reasoned." "316 Stevens' tests were more limited, asking if the prior case is "dead wrong" or "irreconcilable"

313 Iinterpreting polls is a risky business, particularly when applied to more enduring constitutional law. Polls in early 2010, for example, also showed a surge in support for Republicans, who presumably would appoint more Justices favoring Citizens United.

314 Citizens United, 558 at

315 Lawrence v. Texas, 539 U.S. 558, (2003) (Scalia, J., dissenting).

316 Citizens United, 558 U.S. at

(2011) J. JURIS 379 
with prior precedent. Both approaches reflect the insularity of most constitutional rhetoric. In major cases, the outcome is far more important than the "reasoning." And who knows when a case is "wrong," much less "dead wrong?" After all, Kennedy's opinion is filled with legitimate First Amendment norms and metaphors: the challenged law reduced core political speech by criminalizing a limited group of speakers' speech, thereby interfering with the "marketplace of ideas." ".317 But the "marketplace of ideas" metaphor begs the question of "market failure" and "unequal access" to the market (similar to the debate over "unequal bargaining power" that animated Lochner). The deregulated marketplace of ideas favors the best funded ideas, not the best ideas. Still, it is hard to say that Kennedy's approach is "dead wrong;" the text of the First Amendment limits Congressional power to suppress "the freedom of speech." Constitutional law is nothing like math or formal logic, where there really are right and wrong answers. We need to look beyond judicial reasoning to find adequate criteria of "wrongness."

Aristotle observed that the perpetual struggle between the few and the many reflects competing conceptions of "partial justice. ${ }^{318 "} \mathrm{He}$ saw this as a fundamental constitutional question. All classes have legitimate claims that can be framed in terms of equality, justice, and fairness. The poor have "equality of citizenship" and the rich have "equality of merit." It is hard to say how wealth and power should be distributed. There is no magic test determining when a legitimate aristocracy, which provides needed leadership, becomes a perverse oligarchy pursuing its own interests at the expense of the common good. That uncertainty justifies significant judicial restraint concerning the role of money in politics. For those of us who believe that the Court should use its autonomy to limit private power, not enhance $\mathrm{it}^{319}$, the decision is a disaster. Perhaps the system would be more corrupt if Congress had more control over its own elections. But the voters, which the Court seems so concerned about, could throw out legislators to create a more responsive system not premised upon monetary "access." Now, an unelected judiciary has fundamentally changed the electoral playing field. Justice Kennedy may not feel there is any appearance of corruption, but he obviously has not been listening to millions of Americans. For Kennedy, "corruption" is reduced to bribery, which the government can deal with directly via the criminal law.

The opinions briefly considered some consequences of their approaches. Kennedy absurdly noted that giving corporations (which are owned primarily

317 Id. at 38.

318 Aristotle, Politics, in THE Complete Works of Aristotle, Vol II, 2031, (Jonathan Barnes, ed. 1984).

${ }^{319}$ James G. Wilson, Noam Chomsky and Judicial Review, 44 Clev. St. L. Rev. 439 (1996).

(2011) J. JURIS 380 
by wealthy people) more power might level the playing field, because the wealthy individuals already have so much power: "In the 2004 election cycle, a mere 24 individuals contributed an astounding total of $\$ 142$ million to $[26$ U.S.C. $\$ 527$ organizations]." There is another reaction to that appalling fact: starting with Buckley $v$. Valeo, the Supreme Court designed a system that gave the rich excessive political power. Citizens United merely compounds and accelerates the problem. But Kennedy was not worried. He permitted Congress to require disclosure, which Congress may or may not effectively implement. During the 2010 elections, many donors gave millions of dollars to support candidates without disclosure. All other purposes are improper or amorphous. But Kennedy reassures us that the citizenry will not be discouraged. Perhaps he and his colleagues have spent too much time in the corridors of power. A Rasmussen poll in July, 2010, indicates that only twenty-three percent of Americans believe the government has the consent of the governed. ${ }^{32}$

Justice Kennedy and his colleagues claim they are facilitating the electoral process, somehow empowering the electorate by providing them with more corporate propaganda and more powerful lobbyists. It seems indisputable that corporate power will increase as a result of this opinion, that the rich will get richer and the powerful more powerful. Many of us bemoan the collapse of the middle class over the past thirty years, but others embrace the concentration of wealth at the top. The elite prefer a citizenry that is happy to work, consume, and vote for leaders already beholden to powerful interests. Indeed, most candidates in primaries are winnowed out based upon their fund-raising skills. In Discourses on Livy, Machiavelli claimed that republics were a very strong, enduring form of government, because they provide their citizens with many rights, thereby creating a deep allegiance. ${ }^{321}$ So far, the Supreme Court's jurisprudence has profoundly devalued the crucial adhesive of citizenship. There is not just one of Llewellyn's "singing reasons" to overturn this recently decided, closely decided, activist opinion that created a "watershed' moment: there is a symphony.

\section{Conclusion}

Henry Adams observed many years ago in his extraordinary autobiography that human thought and actions tend to fluctuate between universals and particulars. ${ }^{322}$ In some eras, grand abstraction captures the collective

320 Rassmussen Reports, July 2010. http://www.rasmussenreports.com/public_content/politics/general_politics/july_2010. 321 See, Niccolo Machiaveldi, Discourses On Livy (Harvey C. Mansfield \& Nathan Tarcov, trans., 1998) (1517).

322 Henry Adams, The Education of Henry Adams (Oxford Univ. Press 1999) (1919).

(2011) J. JURIS 381 
imagination. During other times, individual details matter more. The Court follows this pattern, shifting between broader, more abstract interpretive techniques (such as Originalism, Textualism, "antisubordination," or Ely's "representation reinforcement") and the more incremental, particularized common law method. It is possible that the United States is entering a less abstract era; the ideological hatreds of the Sixties seem passé in light of current economic and environmental difficulties. Many of the rigid, ideological motifs of contemporary conservatism appear to be fraying. Yet the left is capable of asubstituting its own ideological litmus tests. Even if the nation has been enthralled by a flawed, perverted ideology, it does not follow that many of the Court's recent conservative victories were "wrong" at all, so "wrong" that they ought to be reversed or limited to their facts, or so "wrong" that they have not created a cultural reliance interest that would trigger politically dangerous anger if a resurgent liberal judicial majority undermined those interests. Many liberals, particularly in the academy, will dislike the reluctance to continually constitutionalize the divisive cultural wars. But the average American, irrespective of race, gender, or background, must find common ground, where he or she is not divided and conquered by the culture wars that benefit the elite of both political parties and their patrons.

This inquiry has raised a psychological question. What motives reside within those who tend to prefer law's certainty and continuity-- be it through glorification of stare decisis, an appeal to Framers' Intentions, or the creation of enduring bright line rules--and those who consider law to be inherently dynamic and plastic? Why do some of us gravitate toward a more Platonic conception of static law and enduring forms, and others feel more comfortable with Aristotle's fluid jurisprudence and the Buddha's observation that nothing is permanent? Perhaps one unexplored impulse is the adjudicator's feelings about death. If law is fixed, then life's rate of change is slowed down and death is delayed, if not defeated. Furthermore, one's interpretation of law survives indefinitely. To embrace law's indeterminacy and plasticity is to acknowledge human subjectivity, humanity, and mortality. Death is essential to evolution. Thus, this article concludes with intimations of an existential jurisprudence. 